\title{
Tyrian Purple: 6,6'-Dibromoindigo and Related Compounds
}

\section{Christopher J. Cooksey}

59 Swiss Avenue Watford WD18 7LL, UK; tel +44 1923241 688; fax +44 8700547454

e-mail: dha@chriscooksey.demon.co.uk

Received: 15 August 2001 / Accepted: 20 August 2001 / Published: 31 August 2001

\begin{abstract}
The genesis of the purple dye from shellfish, its composition, origin, intermediates, analysis and synthesis of the components, 6,6'-dibromoindigo, 6bromoindigo and 6,6'-dibromoindirubin are reviewed
\end{abstract}

Keywords: 6,6'-dibromoindigo, 6-bromoindigo, 6,6'-dibromoindirubin, tyrindoxyl, tyriverdin, tyrindoleninone, tyrindolinone, synthesis, structure, properties

\section{Introduction}

6,6'-Dibromoindigo is a major component of the historic pigment Tyrian purple, also known as Royal purple, shellfish purple and Purple of the Ancients. Arguably, it is the oldest known pigment, the longest lasting, the subject of the first chemical industry, the most expensive and the best known. The colour is derived exclusively from marine shellfish of the Muricidae and Thaisidae families. The long history, stretching back well into the pre-chemical era, and embracing chemistry, biology and sociology, contains not a few misconceptions and erroneous conclusions. This review attempts to set the record straight.

This molluscan dye has been known since pre-Roman times and in the Mediterranean region there is evidence for the industry around the 13th century B.C. [1] at Sarepta, now Sarafand, Lebanon. The ancient industry was distributed world-wide [2]. Surviving details of the ancient process are insufficient to explain the chemistry involved and this is the subject of continuing speculation. But it is clear that the dye does not exist in the mollusc and is generated from precursors, sometimes termed chromogens, contained in the hypobranchial gland. 
The process is described by Pliny [3], writing in the 1st century AD:

The vein [hypobranchial gland] already mentioned is then extracted and about a sextarius [ca. $7 \mathrm{lb}$ ] of salt added to each hundred pounds of material. It should be soaked for three days, for the fresher the extract, the more powerful the dye, then boiled in a leaden vessel. Next, five hundred pounds of dye-stuff, diluted with an amphora [about 8 gallons] of water, are subjected to an even and moderate heat by placing the vessels in a flue communicating with a distant furnace.

Meanwhile, the flesh which necessarily adheres to the veins is skimmed off and a test is made about the tenth day by steeping a well-washed fleece in the liquefied contents of one of the vessels. The liquid is then heated till the colour answers to expectations. A frankly red colour is inferior to one with a tinge of black. The wool drinks in the dye for five hours and after carding is dipped again and again until all the colour is absorbed.

In more recent times, a distinctly different process for obtaining the purple has been described, first by Cole in 1685 [4], in which the contents of the hypobranchial gland are spread on to cloth and the colour develops in response to air and light.

\section{The Ancient process}

Meyer Reinhold [5] has reviewed in detail the importance of the purple in ancient Greek and Roman times and a large body of literature has accumulated which has been summarised by Dedekind [6], Becker [7] and in less detail by Born [8-9]. It is generally believed that the dyeing process involved generation of the purple dye from the precursor(s), followed by reduction to a leuco compound and subsequent oxidation on the cloth to give the colour in the same way as modern vat dyes. Much effort has been devoted to the discovery of potential reagents which could have been used at that time to reduce the dibromoindigo to the leuco form. In Pliny's description, the word plumbum has no adjective and depending on whether nigrum ("black") or album ("white") is added, could be translated as either lead or tin. Experiments with lead and tin usually in strongly alkaline solution [10-12] have met with variable success but tin is the stronger reductant [13]. Other suggestions for reducing agents are mercaptans [14]; methane thiol is a potential byproduct but the amount present is small and would be insufficient to convert all the dye into the leuco form. Experiments with dodecanethiol in $1 \mathrm{M} \mathrm{NaOH}$ at 78-88 ${ }^{\circ} \mathrm{C}$ were successful [11]. Honey has been suggested, although the reducing properties of glucose are not very powerful. Experiments with iron reducing systems, mentioned by the ancients, did not succeed, but may have referred to other dyes which were cheap alternatives to the purple.

The alternative suggestion is of a biochemical reduction, analogous to that for indigo in the woad vat, which has recently been shown [15-17] to utilise Isatis clostridium, but was reportedly unsuccessful for dibromoindigo[11]. However, based on the successful woad vat parameters ( $\mathrm{pH} 7.8$; 
$50{ }^{\circ} \mathrm{C}$ ), and the long (10 day) fermentation period, this process has been successful [18] in producing a dye bath from Murex trunculus and reducing synthetic dibromoindigo using cockles [19].

\section{The direct process}

William Cole [4] clearly described this process in which the contents of the hypobranchial gland of Nucella lapillus (at Minehead in the UK) are spread on to linen...

he "found this species on the shores of the Bristol Channel, which on cracking and picking off the shell, exhibited a white vein lying transversely in a little furrow or cleft next the head of the fish; which must be digged out with the stiff point of a horse hair pencil being made short and tapering; which must be so formed by reason of the viscous claminess of that white liquor in the vein so that by its stiffness it may drive in the matter into the fine linnen or white silk ....... if placed in the Sun will change into the following colours, i.e., if in the winter about noon, if in the summer an hour or two after sunrise and so much before setting (for in the heat of the day the colours will come on so fast, that the succession of each colour will scarce be distinguishable) next to the first light green will appear a deep green; and in a few minutes this will change into a dull sea green; after which, in a few minutes more, it will alter into a watchet blue; from that in a little time more it will be purplish red; after which, lying an hour or two (supposing the Sun still shining) it will be of a very deep purple red; beyond which the Sun can do no more."

Every author who describes this process remarks on the distinctive colour changes that take place in the sunlight. In Mediterranean sunshine, the process is complete in less than ten minutes [20,21]. The second notable characteristic is the powerful odour which accompanies the colour development: it is likened to garlic or assafoetidea and is quite distinct from the odour of decomposing shell-fish. Other examples are given by Letellier [22] and Schunck [23]. Réaumur [24] confirmed the need for oxygen in the purple forming process, Duhamel [25] confirmed that light was necessary, but it was left to Lacaze-Duthiers [26] to demonstrate the potential use in photography.

In South America, the direct application route has a long history. Here the species used is Purpura pansa and in contrast to the Mediterranean molluscs, it does not need to be sacrificed to yield the dye. The elements of this dyeing process were described by Juan and de Ulloa [27] in 1744:

On the coasts belonging to the province of Guayaquil the finest purple is found. The animals from which it is derived are contained in shells, about the size of walnuts, and live on rocks washed by the sea. They contain a juice or humour, which is taken out, and yields the true purple. ... Cotton, thread, and other delicate materials are dyed with it. It gives a lively and durable colour, which does not lose its lustre by frequent washings, but is rather improved thereby, and does not fade through long-continued use and exposure. Near the port of Nicoya in the province of Guatemala [now Costa Rica] 
the same kind of shellfish is found and is used for dyeing cotton ... Various processes are employed for extracting the juice or humour. Some kill the animal. They take it out of its shell, and, having laid it on the back of the hand, press and squeeze it with a knife from the head to the tail, and then separate the expressed juice, the rest of the animal matter being thrown away. They treat in this way a number of animals until they have sufficient quantity of juice. They then draw through the thread which they wish to dye, and no more is required ... Others express the juice without killing the animal. They do not take it entirely out of the shell, but only press it so as to cause a certain quantity to be ejected, with which the threads are dyed. The shells are then laid again on the stones from which they were taken. They recover, and after some time give a fresh quantity of juice, but not so much as the first time. If the operation is repeated three or four times, the quantity is very small and the animal dies of exhaustion.

The features which distinguish this process from others are that cotton threads are dyed separately and subsequently woven, and that the mollusc is apparently not harmed by periodic milking. A century later, Squier [28] describes the process on the Pacific coast of Nicaragua:

The process of dyeing the thread illustrates the patient assiduity of the Indians. It is taken to the seaside, when a sufficient number of shells are collected, which being dried from the sea water, the work is commenced. Each shell is taken up singly, and a slight pressure upon the valve which closes its mouth forces out a few drops of the colouring fluid, which is then almost destitute of colour. In this each thread is dipped singly, and after absorbing enough of the precious liquid, is carefully drawn out between the thumb and finger, and laid aside to dry. Whole days and nights are spent in this tedious process, until the work is completed. At first the thread is of a dull blue colour, but upon exposure to the atmosphere acquires the desired tint. The fish is not destroyed by the operation, but is returned to the sea, where it lays in a new stock of colouring matter for a future occasion.

This operation has more recently been described by Nuttall [29] in 1909, Thomson [30] in 1995, Rios-Jara, et al. [31] in 1994 and Michel-Morfin in 2000 [32, 33].

\section{The identity of the purple}

In the nineteenth century, there was gradual progress towards identifying the purple pigment as dibromoindigo. Bizio [34] showed that the pigment from Murex brandaris and Murex trunculus had the characteristics of indigoid pigments; Schunck [24] isolated $7 \mathrm{mg}$ of the dye which he called punicin from 400 Purpura capillus (after which his patience was exhausted). In 1880, Schunck [35] obtained a sample of cotton dyed in this way at Realejo on the West Coast of Nicaragua, said to be made with the extract of Purpura patula. It was a dull purple, harsh to the touch and emitted a peculiar smell. Extraction with warm dilute hydrochloric acid followed by boiling ether brightened the colour. 
He then treated the cloth with boiling aniline, which after a second extraction removed all the colour. After cooling the aniline solution, all the coloured material crystallised. In this way, he obtained 0.099 grams from 24 grams of cloth. The colouring matter had all the properties of punicin, which he had earlier obtained from Purpura capillus.

In 1909 Friedlander [36] solved the identity problem by processing the hypobranchial glands of 12,000 Murex brandaris and obtained 1.4 grams of pigment. The hypobranchial glands were removed from the animals, spread on to filter paper and the colour allowed to develop in sunlight. The filter paper was macerated and heated for 0.5 hour with dilute sulfuric acid (1:2) and after filtration washed with hot water. The residue was Soxhlet extracted with ethanol to remove impurities and then the pigment extracted with ethyl benzoate from which it separated in shining crystals. A second crystallisation from ethyl benzoate and finally from quinoline completed the purification. Elemental analysis showed that it contained bromine, which was unexpected, with an empirical formula $\mathrm{C}_{16} \mathrm{H}_{8} \mathrm{Br}_{2} \mathrm{~N}_{2} \mathrm{O}_{2}$. An unsymmetrically substituted indigo is unlikely since the precursor would be a $\mathrm{C} 16$ compound, but the precursor is not coloured, and of the four symmetrical isomers of dibromoindigo, two of which were then known, 5,5'- and 6,6'-, the latter was the most similar. Two syntheses confirmed the conclusion. Confirmation that dibromoindigo is the major coloured component of Tyrian purple has been repeated for many mollusc species over the years. The rapid advance in analytical techniques in the second half of the 20th century has greatly reduced the effort required. A summary of the techniques used is shown in Table 1.

Table 1. Methods used to identify dibromoindigo in molluscs and on artefacts.

\begin{tabular}{|l|l|l|l|}
\hline Authors & Date & Species / artefact & Technique(s) \\
\hline Friedlander [36] & 1909 & Murex brandaris & elemental analysis \\
\hline Friedlander [37] & 1922 & $\begin{array}{l}\text { Purpura lapillus } \\
\text { Purpura aperta }\end{array}$ & elemental analysis \\
\hline Driessen L A [38] & 1944 & textile & $\begin{array}{l}\text { photodebromination of } \\
\text { leuco-dibromoindigo }\end{array}$ \\
\hline van Alpen [39] & 1944 & textile & $\begin{array}{l}\text { photodebromination of } \\
\text { leuco-dibromoindigo }\end{array}$ \\
\hline Bruin [40] & 1966 & Murex trunculus & $\begin{array}{l}\text { ESR } \\
\text { elemental analysis; MS }\end{array}$ \\
\hline Baker \& Sutherland [41] & 1968 & Dicathais orbita & IR, X-RAY \\
\hline $\begin{array}{l}\text { Gibaja Oviedo \& Salazar } \\
\text { de Cavero [43] }\end{array}$ & 1977 & Chanque (Peru) & \begin{tabular}{l} 
UV/VIS \\
\hline Taylor G W [44]
\end{tabular} \\
\hline McGovern \& Michel [45] & 1985 & Sarepta pot shard & $\begin{array}{l}\text { PIXE, ESCA, FTIR, } \\
\text { photodebromination of } \\
\text { leuco-dbi }\end{array}$ \\
\hline Daniels [46,47] & 1985 & textile from Enkomi & VIS \\
\hline
\end{tabular}




\begin{tabular}{|l|l|l|l|}
\hline $\begin{array}{l}\text { McGovern, Lazar, Michel } \\
{[48,49]}\end{array}$ & 1990 & $\begin{array}{l}\text { Peruvian textiles } \\
\text { Paracas (900-200BC) } \\
\text { Nazca (200BC-600AD) } \\
\text { Purpura patula pansa }\end{array}$ & MS \\
\hline Wouters [50] & 1991 & HPLC \\
\hline $\begin{array}{l}\text { Koren 1995 } \\
\text { [51] }\end{array}$ & 1994 & Murex trunculus & HPLC \\
\hline $\begin{array}{l}\text { Kosugi Y \& Matsumoto } \\
\text { K 1994 [52] }\end{array}$ & 1994 & Rapana venosa & MS \\
\hline $\begin{array}{l}\text { Shimoyama S \& Noda Y } \\
\text { 53] }\end{array}$ & 1994 & Rapana thomasiana & 3D fluorescence spectra \\
\hline $\begin{array}{l}\text { Clark \& Cooksey [54] } \\
\text { Cooksey \& Withnall [55] }\end{array}$ & 1997 & Nucella lapillus & HPLC \\
\hline Shimoyama S [56] & 1999 & coloured textile remnant & 3D fluorescence spectra \\
\hline $\begin{array}{l}\text { Cooksey, Withnall, Patel, } \\
\text { Naegel [57] }\end{array}$ & 2000 & Purpura pansa & HPLC \\
\hline
\end{tabular}

In 1922, Friedlander [37] speculated that there was a second blue more soluble component in Tyrian purple, but at that time, it could not be identified. The HPLC of indigoid dyes, pioneered by Wouters and Verhecken [97], revealed that the more soluble blue component is 6-bromoindigo and that there is another minor component, 6,6'-dibromoindirubin. Pigments derived from Murex trunculus are more complex and variable, containing also indigo and indirubin.

\section{The synthesis of 6,6'-dibromoindigo}

The first synthesis was reported by Sachs and Kempf (Figure 1a) [58] in 1903. They obtained 4bromo-2-nitrobenzaldehyde from 2-nitro-4-aminobenzaldoxime by diazotisation in $\mathrm{HBr}$ and reacted it with acetone and alkali in the classic Bayer-Drewson [59] indigo synthesis manner to give dibromoindigo. The product dissolved in hot aniline to give a blue solution and precipitated as an amorphous solid on cooling. A year later Sachs and Sechel (Figure 1b) [60] published another synthesis from 2-nitro-4-bromophenyl lactic acid ketone. Friedlander (1909) used two methods: starting with 4-bromo-2-nitrobenzaldehyde as above and also from 4-bromo-2-methylaniline via Nacetyl-6-bromoindoxyl (Figure 1c).

Figure 1(a). Sachs and Kempf (1903) [58].<smiles>Nc1ccc(C(=O)O)c([N+](=O)[O-])c1</smiles><smiles></smiles><smiles>O=Cc1ccc(Br)cc1[N+](=O)[O-]</smiles> 
Figure 1(b). Sachs and Sichel (1904) [60].<smiles>O=Cc1ccc(Br)cc1[N+](=O)[O-]</smiles>

$\mathrm{NaOH}$ or

$\mathrm{Na}_{2} \mathrm{CO}_{3}$

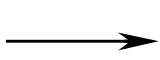

acetone

$\mathrm{Na}_{3} \mathrm{PO}_{4}$<smiles>CC(=O)CC(O)c1ccc(Br)cc1[N+](=O)[O-]</smiles>

Figure 1(c). Friedlander (1909) [36].<smiles>Cc1ccc(Br)cc1N</smiles>

$\stackrel{\text { oxidation }}{\longrightarrow}$<smiles>Nc1cc(Br)ccc1C(=O)O</smiles><smiles>O=C(O)CCCCCCCCCCCCCO</smiles><smiles>O=C(O)CNc1cc(Br)ccc1C(=O)O</smiles>

$\mathrm{Ac}_{2} \mathrm{O}, \mathrm{AcONa}$<smiles></smiles>

$\mathrm{NaOH}, \mathrm{O}_{2}$

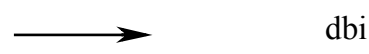

Figure 1(d). Grandmougin and Seyder (1914) [61].<smiles>Nc1ccc2c(c1)NC(=C1Nc3cc(N)ccc3C1=O)C2=O</smiles> 
Grandmougin and Seyder (1914) (Figure 1d) [61] diazotised 6,6'-diaminoindigo in $\mathrm{HBr}$ to obtain dibromoindigo. Subsequently, all syntheses rely on 4-bromo-2-nitrobenzaldehyde as the key intermediate, followed by the Bayer-Drewson indigo synthesis, or the Harley-Mason [62] modification thereof, which appears to give higher yields. In this modification [91], a solution of $\mathrm{CH}_{3} \mathrm{ONa} / \mathrm{CH}_{3} \mathrm{OH}$ is added to a mixture of 4-bromo-2-nitrobenzaldehyde and nitromethane to give yellow crystalline sodium 1-(4-bromo-2-nitrophenyl)-2-nitro ethanolate. This product is dissolved in cold aqueous $\mathrm{NaOH}$ solution and solid $\mathrm{Na}_{2} \mathrm{~S}_{2} \mathrm{O}_{4}$ added. Aerial oxidation completes the reaction.

4-Bromo-2-nitrobenzaldehyde can be prepared (Barber and Stickings, Figure 1e [63]) from 4bromo-2-nitrotoluene by $\mathrm{CrO}_{3}$ /acetic anhydride oxidation to give 4-bromo-2-nitrobenzylidene diacetate which was then hydrolysed by boiling in aqueous-ethanolic sulfuric acid. The aldehyde was purified via the bisulfite compound and was obtained in an overall yield of $17.5 \%$. Using the same process, Pinkney and Chambers (Figure 1e) [64] obtained 14.1\% yield and Torimoto, Morimoto and Shingaki (Figure 1d) [65] obtained 13.1\%.

Figure 1(e). Barber and Stickings (1945) [63]; Pinkney and Chambers (1979) [64] Torimoto, Morimoto and Tadao (1991) [65].<smiles>Cc1ccc(Br)cc1[N+](=O)[O-]</smiles><smiles>CC(=O)c1ccc(Br)cc1[N+](=O)[O-]</smiles><smiles>O=Cc1ccc(Br)cc1[N+](=O)[O-]</smiles>
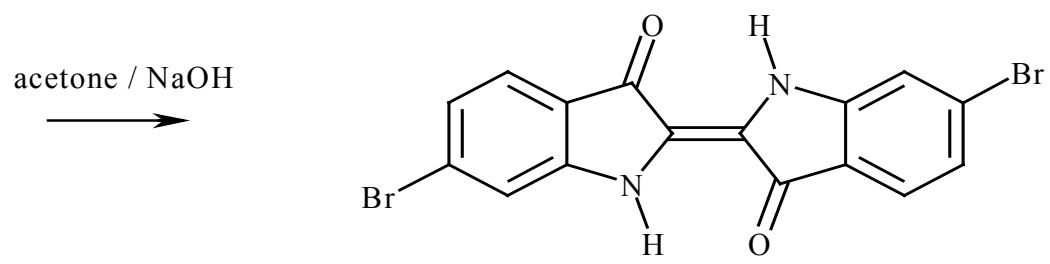

An entirely different route to 4-bromo-2-nitrobenzaldehyde has been disclosed by Voss and Gerlach (Figure 1f) [66] which entails selective lithiation of 1,4-dibromo-2-nitrobenzene followed by reaction with dimethylformamide to give the product in $92 \%$ yield. This is attractive since 1,4dibromobenzene can be nitrated in nearly quantitative yield under mild conditions using nitric acid in trifluoroacetic anhydride [67], but the low temperature and complete absence of oxygen required for the lithiation present some problems. An alternative route from 4-bromo-2-nitrotoluene to 4-bromo-2nitrobenzaldehyde involves benzylic bromination followed by the Kröhnke reaction (Figure 1g) [68]. Although multi-step, each reaction proceeds in high yield and purification at each stage is not necessary [69]. These syntheses are summarised in Figure 1. 
Figure 1(f). Voss and Gerlach (1989) [66].<smiles>O=[N+]([O-])c1cc(Br)ccc1Br</smiles>

1) BuLi 2) DMF<smiles>O=Cc1ccc(Br)cc1[N+](=O)[O-]</smiles>

1) $\mathrm{CH}_{3} \mathrm{NO}_{2}, \mathrm{CH}_{3} \mathrm{ONa}$

2) $\mathrm{Na}_{2} \mathrm{~S}_{2} \mathrm{O}_{4}$<smiles>O=C1C(=C2Nc3cc(Br)ccc3C2=O)Nc2cc(Br)ccc21</smiles>

Figure 1(g). Cooksey (1994) [69].<smiles>Cc1ccc(Br)cc1[N+](=O)[O-]</smiles><smiles>CN(C)c1ccc(/[N+]([O-])=C/c2ccc(Br)cc2[N+](=O)[O-])cc1</smiles><smiles>O=Cc1ccc(Br)cc1[N+](=O)[O-]</smiles>

1) $\mathrm{CH}_{3} \mathrm{NO}_{2}, \mathrm{CH}_{3} \mathrm{ONa}$

2) $\mathrm{Na}_{2} \mathrm{~S}_{2} \mathrm{O}_{4}$<smiles>N#Cc1ccc2c(c1)N/C(=C1\Nc3cc(Br)ccc3C1=O)C2=O</smiles>

How ever it is produced, dibromoindigo is easily purified, being only slightly soluble in most organic solvents at room temperature. The crude material can be washed with copious amounts of water and ethanol without loss. But, when first formed, sufficient time must be allowed for the finely divided material to aggregate (a day or two or even a week), otherwise it will pass through a filter. 
Recrystallisation can be achieved using a variety of high boiling solvents (methyl benzoate, ethyl benzoate or quinoline, $80 \mathrm{~cm}^{3} /$ gram).

\section{The properties of 6,6'-dibromoindigo}

The principal physical characteristics of the compound are the insolubility in solvents, high melting temperature and intense colour.

\section{(a) Visible spectrum}

The colour of the compound is various shades of purple depending on the particle size and, when crystalline, it is black with a copper lustre as are many compounds with a high light absorption: the distance the light travels through a crystal is less than the wavelength of the light.

The indigo molecule has long been subjected to theoretical investigations into the reason for the blue colour. A successful outcome is described by Lüttke and Klessinger in 1964 [70] and the chromophore turns out to be the indigo molecule but without the benzene rings as shown in Figure 2 [71]. The topic is still being investigated [72].

Figure 2. The chromophore of indigo.

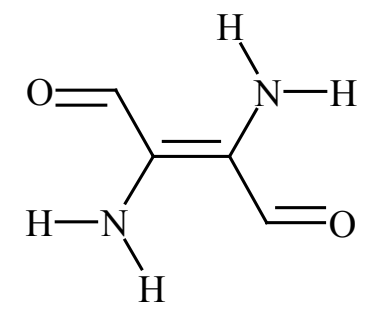

There is a quite extraordinary difference between the colour of dyed cloth (purple) and the colour of the dye in solution (blue). Since the visible absorption spectrum of indigo dyes is readily measured, the variation of the wavelength of maximum absorption $\left(\lambda_{\max }\right)$ with solvent, concentration, temperature and chemical substituent on the indigo ring has been extensively investigated. Bromination of the indigo ring actually has quite a small effect on $\lambda_{\max }$ as shown in Table 2 .

Table 2. Visible absorption spectrum maxima $\left(\lambda_{\max }\right)$ of various brominated indigo dyes.

\begin{tabular}{|l|l|l|l|}
\hline Bromine substituent(s) & Solvent & $\lambda_{\max } / \mathrm{nm}$ & reference \\
\hline $6,6^{\prime}-$ & tce & 585 & {$[73]$} \\
\hline $6,6^{\prime}-$ & $\mathrm{xyl}$ & 590.5 & {$[74]$} \\
\hline $6-$ & tce & 601 & {$[75]$} \\
\hline $7,7^{\prime}-$ & tce & 605 & {$[73]$} \\
\hline none & tce & 605 & {$[76]$} \\
\hline $7-$ & tce & 605 & {$[75]$} \\
\hline
\end{tabular}




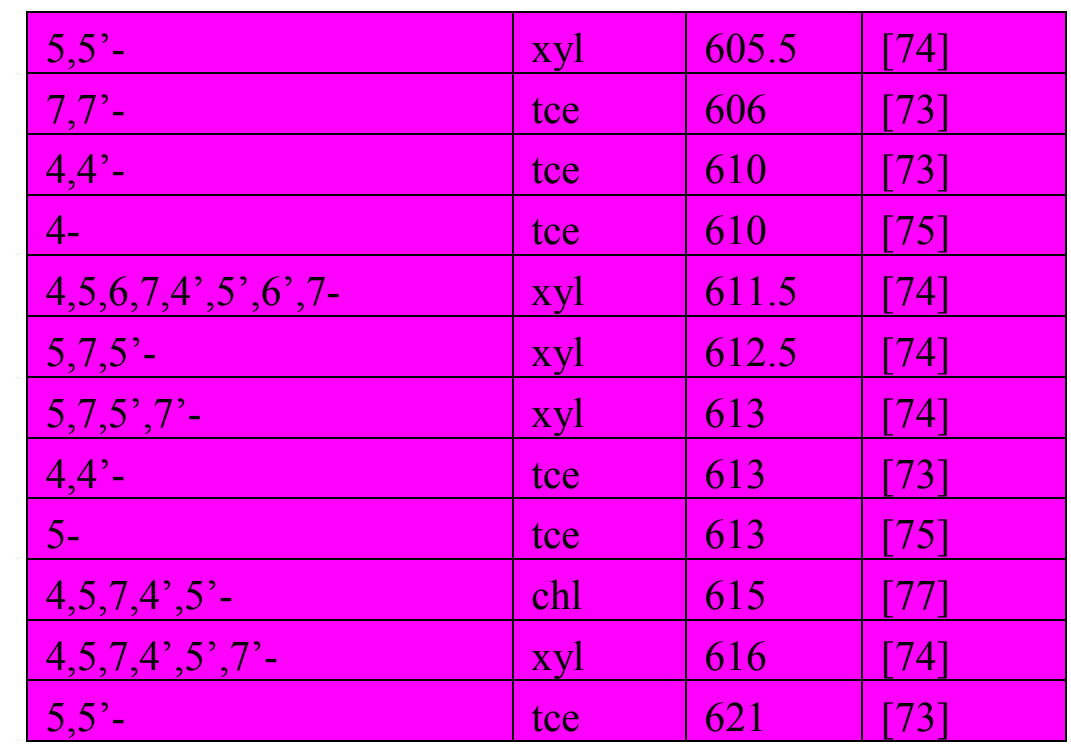

Solvents: tce $=1,1,2,2$-tetrachloroethane; $\mathrm{xyl}=$ xylene; $\mathrm{chl}=$ chloroform.

With solutions of indigo there is some evidence of an absorption at higher wavelength which has been ascribed to a dimer in solution [78] since the intensity increases with concentration and decreases with temperature. The effect is shown for indigo solutions in 1,2-dichloroethane in Figure 3. This phenomenon has been observed for some of the monobromoindigo compounds, but not for dibromo compounds which have a lower solubility. A similar situation may exist in aqueous solutions of indigo carmine (indigo disulfonic acid) [79]. This could be important for those analytical chemists who measure indigo concentrations spectrophotometrically.

Figure 3. The variation of absorption spectrum of indigo in 1,2-dichloroethane with concentration (a) and temperature (b) [78].

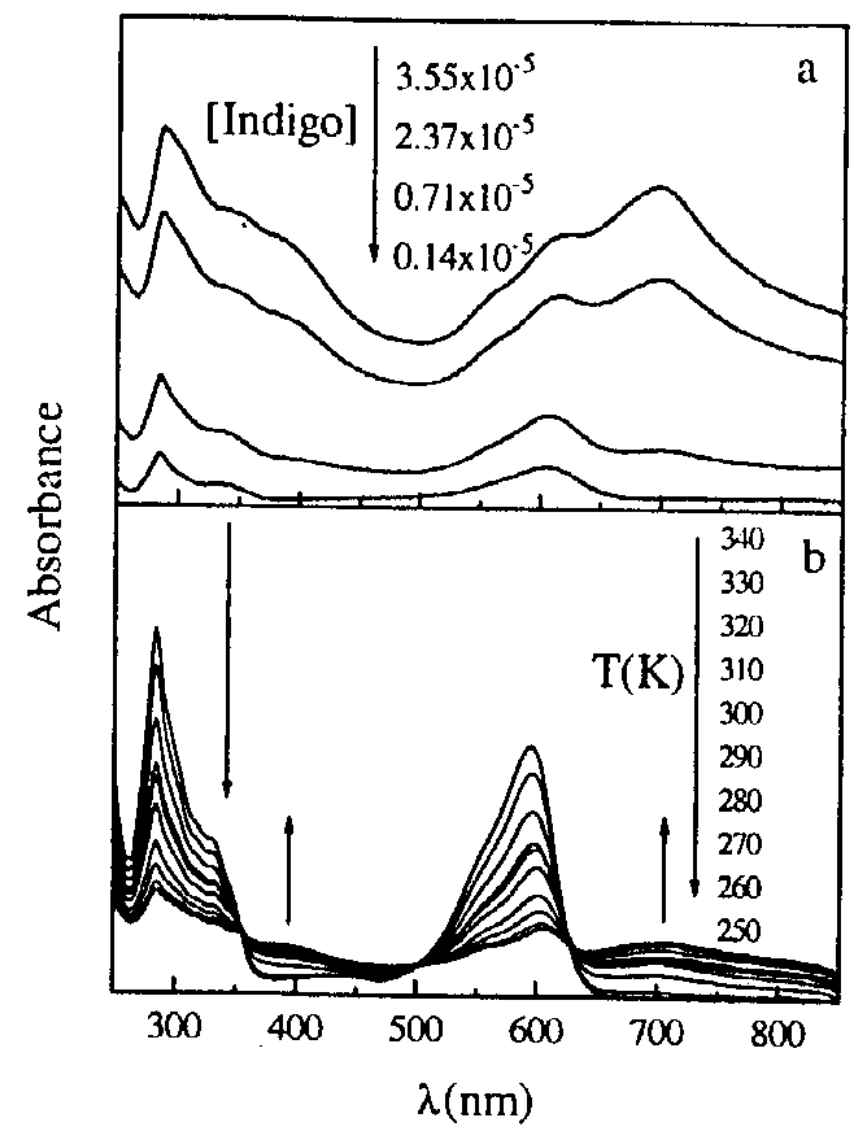


In contrast to the blue colour in solution, the colour of dibromoindigo-dyed cloth is purple. The visible reflectance spectra of indigo and dibromoindigo dyed cloth are shown in Figure 4 [75]. The absorption maximum of indigo shifts from $605 \mathrm{~nm}$ in solution to about $680 \mathrm{~nm}$ as a dye, whereas that of dibromoindigo shifts from $590 \mathrm{~nm}$ to $520 \mathrm{~nm}$. The reasons for this difference are considered in more detail in the section on structure, but essentially result from the interaction of two dibromoindigo molecules. Maya blue [80-82] is an interesting pigment of antiquity in which indigo molecules are inserted into a clay layer matrix. In this situation interaction between two rings in dibromoindigo molecules is not possible and the colour of the dibromoindigo analogue of Maya blue is blue [83]. The blue colour of dibromoindigo in the solid state has been observed over the centuries in the colour changes during the generation of the pigment from shellfish. Here the molecules are generated with a random orientation in a solid matrix and only after re-orientation does the blue colour change to purple. In the same way, it has been observed that dyeing silk [75] at a low concentration gives rise to a blue colour and this may be caused by the way the dibromoindigo molecules are bound to the silk which precludes an easy re-orientation to give molecules in which the rings are closely associated.

Figure 4. The visible reflectance spectra of indigo and dibromoindigo dyed wool [75].

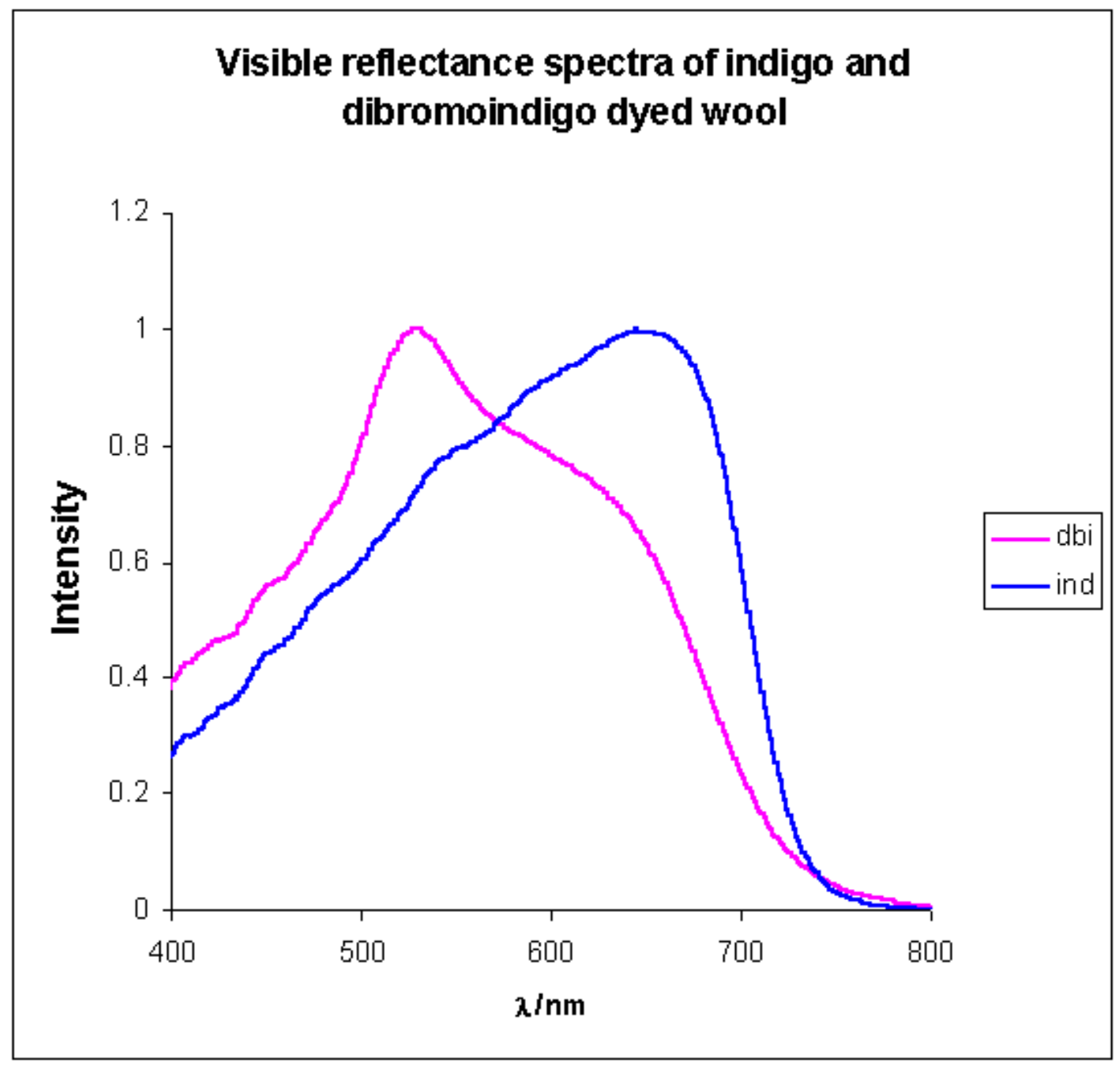




\section{(b) IR and Raman spectra}

The IR spectrum of dibromoindigo shows the expected characteristic peaks at $3300 \mathrm{~cm}^{-1}(\mathrm{NH}$ stretch) and $1630 \mathrm{~cm}^{-1}(\mathrm{C}=\mathrm{O}$ stretch $)[66,75,84]$ and has been used for characterisation purposes, although it is reported that results depend on the method of preparation [84]. A complete analysis of the IR and NIR-FT Raman spectra for indigo has been published [85]; comparable results for dibromoindigo are not yet available. The near-infrared FT Raman spectrum of dibromoindigo, in contrast to the IR spectrum, shows the strongest peak at $1582 \mathrm{~cm}^{-1}(\mathrm{C}=\mathrm{C}$ stretch). These spectra are illustrated in Figure 5.

Figure 5. IR (above) and FT-Raman (below) spectra of 6,6'-dibromoindigo [75].
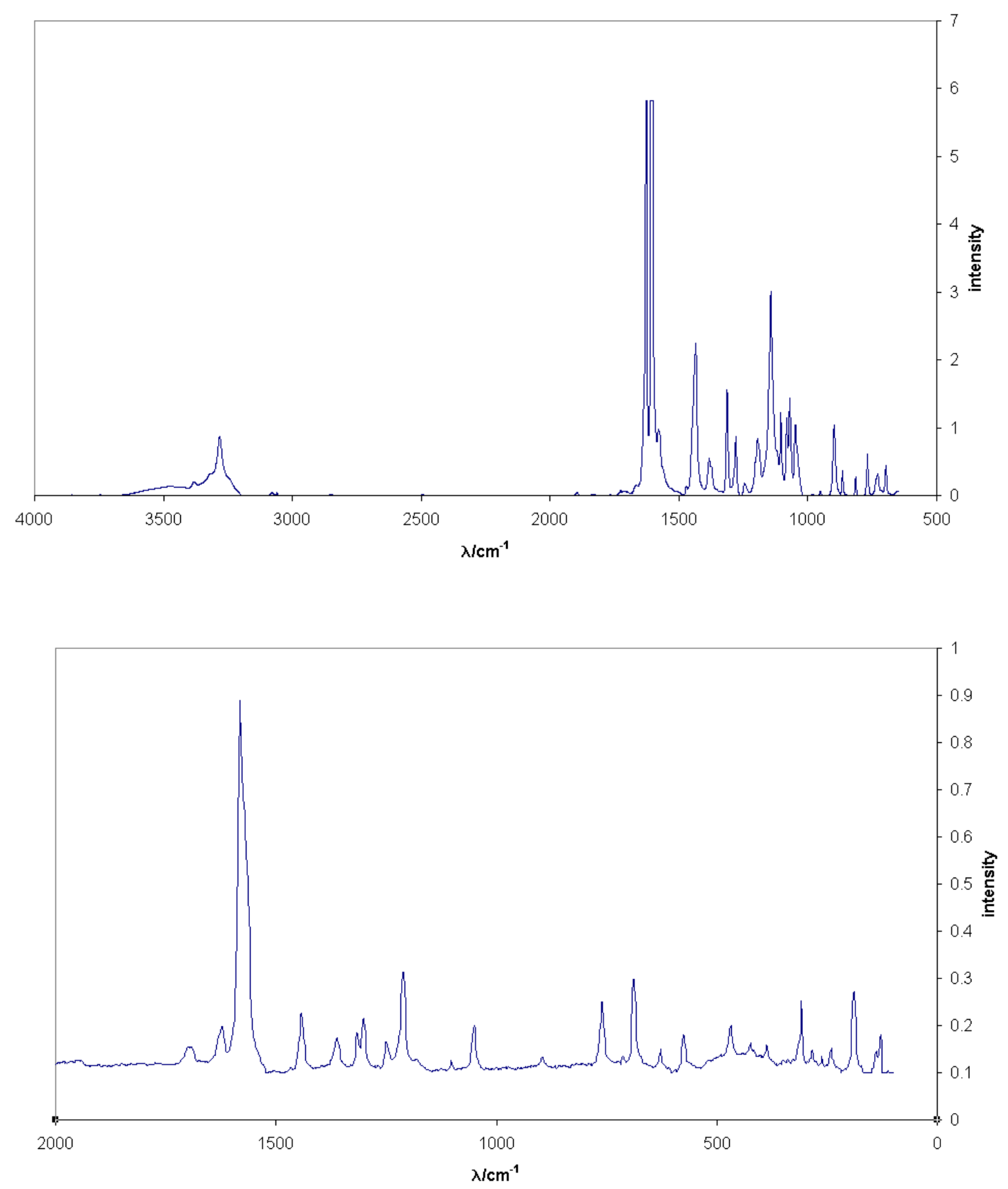


\section{(c) NMR spectra}

It is just possible to directly observe the NMR spectrum of indigo [86], but the insolubility in the usual solvents at normal temperatures precludes this for dibromoindigo. The observation of the solid state NMR spectrum should be possible, but has not been reported. The solubility problem has been circumvented in two ways. The first is to derivatise the dibromoindigo by reaction with trifluoroacetic anhydride to give the N,N'-bis(trifluoroacetyl)-6,6'-dibromoindigo [69] which then shows the three proton multiplets in the ${ }^{1} \mathrm{H}-\mathrm{NMR}$ spectrum at $\delta_{\mathrm{H}} 8.28 \mathrm{~d}(1.3), 7.75 \mathrm{~d}(8.3), 7.56 \mathrm{dd}(8.1,1.5)$. The second route is to reduce the dibromoindigo in $\mathrm{D}_{2} \mathrm{O}$ with $\mathrm{Na}_{2} \mathrm{~S}_{2} \mathrm{O}_{4}$ [87] to give leuco-dibromoindigo which then shows $\delta_{\mathrm{H}} 7.50 \mathrm{~d}(1.8), 7.48 \mathrm{~d}(8.4), 7.09 \mathrm{dd}(8.4,1.6)$. These structures are shown in Figure 6.

Figure 6. Derivitisation of dibromoindigo for NMR determination.<smiles>O=C1C(=C2Nc3[nH]c4cc(Br)ccc4c3N2)c2ccc(Br)cc21</smiles>
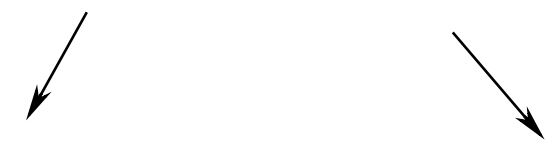<smiles>[R]N1/C(=C2/c3ccc(Br)cc3N2[R])C(=O)c2ccc(Br)cc21</smiles>

$\mathrm{R}=\mathrm{COCF}_{3}$ $\mathrm{N}, \mathrm{N}$-bis(trifluoroacetyl)-dibromoindigo<smiles>[O-]c1c(-c2[nH]c3cc(Br)ccc3c2[O-])[nH]c2cc(Br)ccc12</smiles>

leuco-dibromoindigo

\section{(d) MS}

The mass spectrum of dibromoindigo shows the characteristic signature of a compound with two bromine atoms in the molecule: a 1:2:1 triple peak with 2 mass unit spacing centred at $\mathrm{m} / \mathrm{z} 420$. First reported by Baker [41], the technique was widely used by McGovern et al [48] to detect dibromoindigo in dyed materials. Because of the involatile nature of the compound, high injection temperatures need to be used and if the substrate is mixed with other organic matter such as textile fragments, reduction can occur and the resulting MS shows the presence of 6-bromoindigo [49]. This problem is circumvented by extraction of the dye with a hot solvent such as DMSO or DMF and using that solution to determine the MS. The spectrum shows little fragmentation, reflecting the stability of the molecule, and does not distinguish between dibromoindigo and dibromoindirubin which have the 
same molecular formula. The spectrum is illustrated in Figure 7 [88] and has been reported elsewhere $[48,89]$. The N,N'-bis-trifluoroacetyl-indigo derivative has been used to detect indigo on paper samples via CI-MS [90] and this technique is expected to be equally successful with the dibromo analogue.

Figure 7. The mass spectrum of 6,6'-dibromoindigo [88].

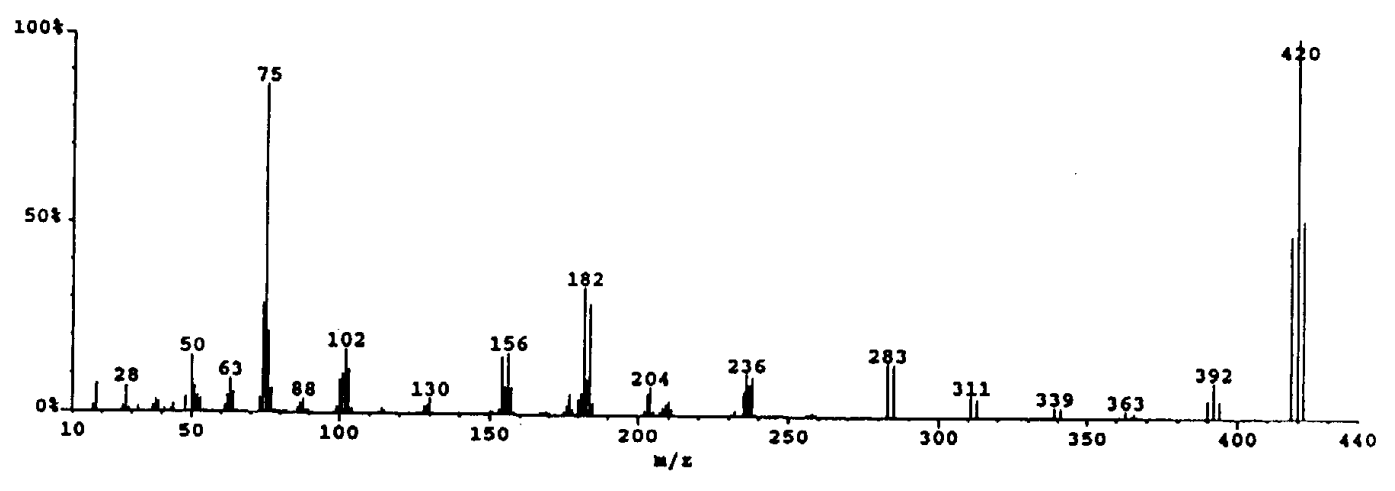

\section{(e) The structure}

In 1880, Bayer drew the structure of indigo as the cis isomer [91]. This was the convention until the 1920s when spectroscopic and other evidence suggested otherwise [92]. It was Hélène von Eller's crystallographic studies [93] of indigo in 1954 that finally confirmed the trans structure. The X-ray structure of dibromoindigo was has been determined by Süsse and Krampe [94] and Larsen and Watjen [95]. The parameters are monoclinic, space group P21/c, $a=12.609, b=4.842, c=11.611$, $\beta=104.42$ and $Z=2$ [95], and the molecule is practically planar with deviations of less than $0.05 \AA$. Each molecule is hydrogen bonded to four others. The crucial difference between the structures of indigo and dibromoindigo is the distance apart of the two parallel molecules: in indigo it is $5.77 \AA$ [96], but in dibromoindigo it is $4.82 \AA$, caused by van der Waals attraction between the bromine atoms [75]. Quantum mechanical calculations confirm that this aggregation causes a shift in absorption maximum to lower wavelength in the case of dibromoindigo.

\section{The analysis of Tyrian purple}

In 1880, Edward Schunck [35] suggested that indigo, indirubin and dibromoindigo could be distinguished by an observation of their sublimation temperatures: 140,170 and $190{ }^{\circ} \mathrm{C}$. Other analytical techniques of the day were the measurement of the absorption spectrum (recorded photographically on a plate) and an examination of the morphology under a microscope.

There is a need for the detection and quantification of purple pigments on artefacts where often the amount of material is small. As seen in Table 1, MS is a convenient technique for qualitative analysis of the purple, IR has been used and in recent years HPLC is the method of choice. Single wavelength detection is useful, but diode-array detection has the advantage of providing both a retention time parameter and an absorption spectrum. An example is shown in Figure 8. In the future hyphenated techniques such as HPLC-MS may provide more sophistication. 
Figure 8. HPLC of (A) a mixture of (a) indigo, (b) indirubin, (c) 6-bromoindigo, (d) 6-bromoindirubin, (e) 6,6'-dibromoindigo and (f) 6,6'-dibromoindirubin, with retention times (minutes) and (B) the dye from Nucella lapillus [98].

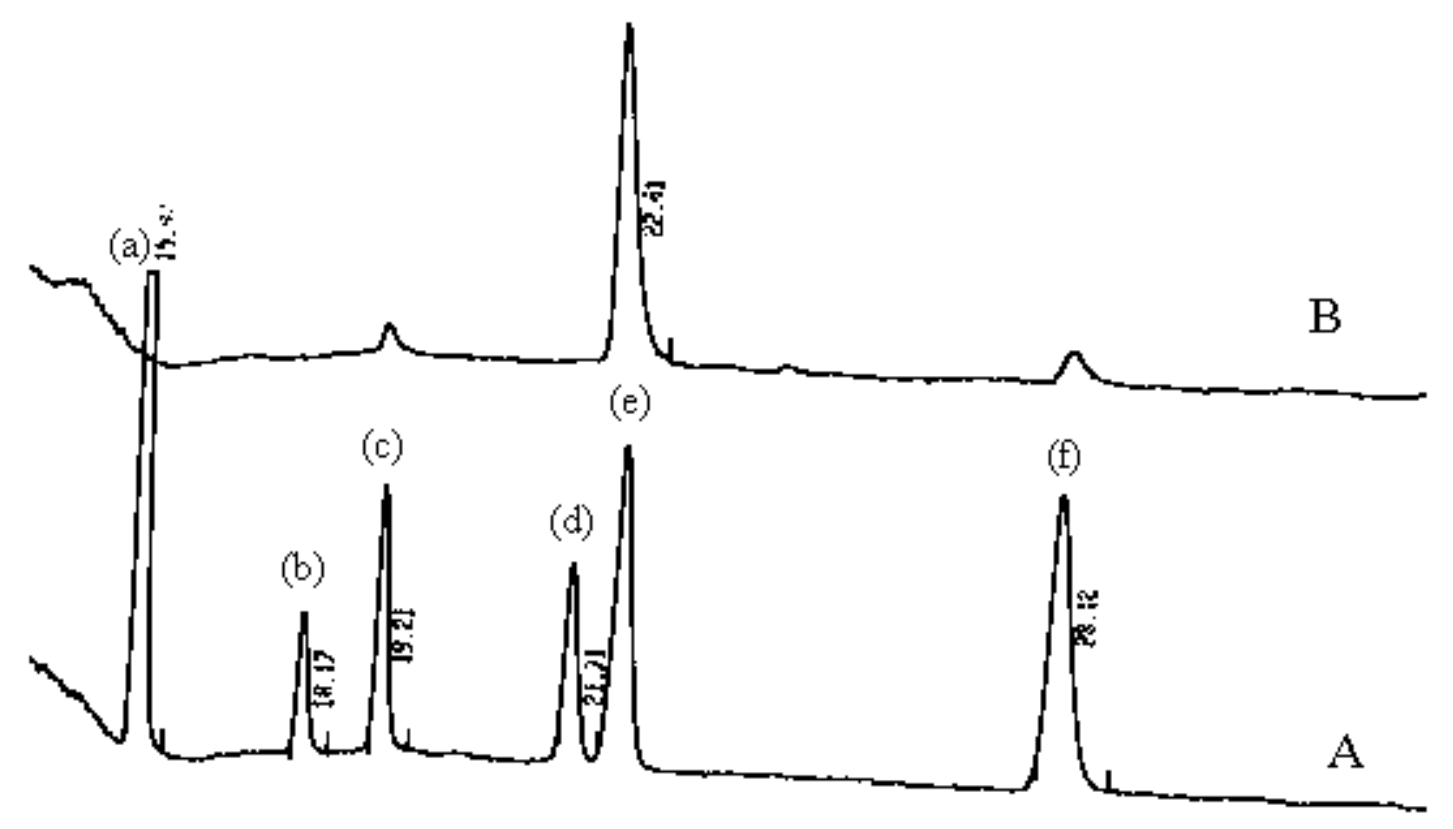

Typical results of the HPLC analysis of Tyrian purple from different mollusc sources is shown in Table 3.

Table 3. The composition of the indigoid constituents of the purple dye from various molluscs.

\begin{tabular}{|c|c|c|c|c|c|c|}
\hline Mollusc species & $\begin{array}{l}\infty \\
: \\
: \\
\Xi \\
\end{array}$ & 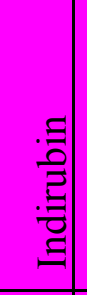 & 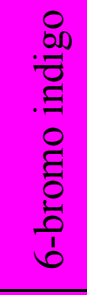 & 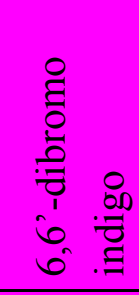 & 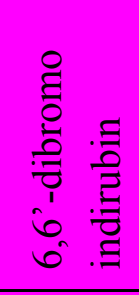 & Reference \\
\hline Murex brandaris & 0 & 0 & 3 & 83 & 14 & [97] \\
\hline Thais haemastoma & 0 & 0 & 3 & 91 & 6 & [97] \\
\hline Nucella lapillus & 0 & 0 & 3 & 88 & 9 & [98] \\
\hline Nucella lapillus & 8 & 0 & 1 & 77 & 14 & [57] \\
\hline Purpura pansa & 0 & 0 & 9 & 90 & 1 & [57] \\
\hline Purpura pansa & 0 & 0 & 16 & 77 & 7 & [99] \\
\hline Murex trunculus & 55 & 7 & 35 & 3 & 0 & [97] \\
\hline Murex trunculus & 4 & 0 & 18 & 76 & 2 & [51] \\
\hline
\end{tabular}


Excluding Murex trunculus which contains non-brominated pigments, the major component of the purple, 77-91\%, is 6,6'-dibromoindigo with smaller amounts of 6-bromoindigo (1-16\%) and 6,6'dibromoindirubin (1-14\%). The origin of these minor components will be considered later.

For those with less resources, TLC is attractive. The intense colour should be easily detected. But at normal temperatures dibromoindigo is not soluble in the solvents which are required for TLC, leading to the incorrect conclusion that it is not mobile on TLC. Because of intermolecular hydrogen bonding, the molecule as a whole is not polar and requires a non-polar solvent for a substrate like silica gel. The solubility problem can be overcome by using high boiling solvents and $100-120{ }^{\circ} \mathrm{C}$ as was demonstrated by Bide and Choi in 1992 [100] for 19 vat dyes including indigo. Although attractive, there are technical problems with a simple beaker on a hot plate apparatus.

Table 4. $\mathrm{R}_{\mathrm{f}} \mathrm{S}$ of $\mathrm{N}$-monoacetylindigos in various solvent mixtures.

\begin{tabular}{|l|l|l|l|}
\hline \multirow{2}{*}{ Solvent } & \multicolumn{3}{|c|}{$\mathrm{R}_{\mathrm{f}}$} \\
\cline { 2 - 4 } 3:2 ethyl acetate - cyclohexane & Indigo & 6 6-Bromoindigo & 6,6 '-Dibromoindigo \\
\hline $1: 9$ methanol - chloroform & 0.79 & 0.58 & 0.62 \\
\hline $1: 1$ benzene - chloroform & 0.14 & 0.80 & 0.81 \\
\hline
\end{tabular}

In the solvents tried, the separation of the monoacetylated brominated indigos was too small to be useful for identification purposes. Replacing acetic anhydride with trifluoroacetic anhydride and warming to $30^{\circ} \mathrm{C}$ gives N,N'-bis(trifluoroacetyl) derivatives. The reaction is self-indicating: the initial violet colour, due to the monoacylindigo, changes to orange when the reaction is complete. TLC then gives two spots on development, a more mobile orange spot of the N,N'-bis(trifluoroacetyl)-indigo and a violet spot for N-trifluoroacetyl-indigo which results from hydrolysis. After standing in the air for $0.5 \mathrm{hr}$ both spots changed colour to blue (indigo) or purple (dibromoindigo) indicating complete hydrolysis. This hydrolytic instability leading to two spots suggests that this method would be of limited utility for mixtures of brominated indigos. Typical $\mathrm{R}_{\mathrm{f}} \mathrm{s}$ are shown in Table 5 .

Table 5. $\mathrm{R}_{\mathrm{f}} \mathrm{s}$ of $\mathrm{N}$-monotrifluoroacetylindigos and N,N'-bis(trifluoroacetyl)indigos in various solvent mixtures.

\begin{tabular}{|l|l|l|l|l|}
\hline \multirow{2}{*}{ Solvent mixture } & \multicolumn{4}{|c|}{$\mathrm{R}_{\mathrm{f}}$} \\
\cline { 2 - 5 } & \multicolumn{2}{|c|}{ indigo } & dibromoindigo \\
\cline { 2 - 5 } & mono & bis & mono & bis \\
\hline 3:2 toluene - ethyl acetate & 0.63 & 0.74 & 0.75 & 0.85 \\
\hline 3:2 heptane - ethyl acetate & 0.47 & 0.54 & 0.56 & 0.63 \\
\hline 3:1 hexane - ethyl acetate & 0.23 & 0.34 & 0.34 & 0.43 \\
\hline 1:1 dichloromethane - ethyl acetate & 0.15 & 0.27 & 0.22 & 0.40 \\
\hline 1:1 chloroform - ethyl acetate & 0.06 & 0.15 & 0.16 & 0.35 \\
\hline 3:2 heptane - dichloromethane & 0.07 & 0.15 & 0.14 & 0.26 \\
\hline
\end{tabular}


Other derivatives need to be investigated before derivatisation can be considered as a viable technique for identification.

\section{The precursors of the purple.}

In the 19th century, Schunck [23] observed that a yellow crystalline material accompanied the generation of the purple from Purpura capillus, but was unable to identify it. Letellier [22] made progress with the same species, isolating the same yellow light insensitive material (xantho-lapilline) and two others which were colourless and water soluble (leuco-lapilline) and green and ether soluble (chloro-lapilline) and which on exposure to light gave the purple. In 1954 Bouchilloux and Roche $[102,103]$ isolated two prochromogens from Murex trunculus which were colourless and water soluble. This investigation was taken further by Malaszkiewicz [104] in 1967 and Fouquet [105, 106] in 1970 who elucidated the structures of four prochromogens which were brominated and nonbrominated indoxyl sulfates. These are shown in Figure 9 compounds 1 - 4. 4 was also detected as the single precursor in Murex brandaris, Murex erinaceus and Purpura haemastoma, but this observation has not been confirmed.

Figure 9. Precursors to the purple colour in muricids.

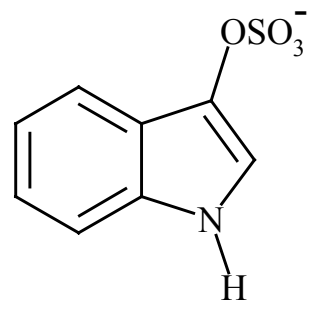

1<smiles>O=S(=O)(O)Oc1c[nH]c2cc(Br)ccc12</smiles>

3<smiles></smiles>

2<smiles></smiles>

4<smiles></smiles> 
Meanwhile Baker and Sutherland [41] isolated a single different brominated indoxyl sulfate precursor, Figure 9 compound 5, which they named tyrindoxyl sulfate from Dicathais orbita.

The complexity of the purple precursors from different species is well illustrated by paper chromatography of an ethanol extract of the hypobranchial glands as shown by Baker [84] and reproduced in Figure 10.

Figure 10. Paper chromatography of ethanol extracts of purple molluscs, Dicathais orbita, Murex brandaris, Murex trunculus, Purpura haemastoma, Murex erinaceus and Rapana bezoar compared with potassium indoxyl sulfate (K.I.S) [84].

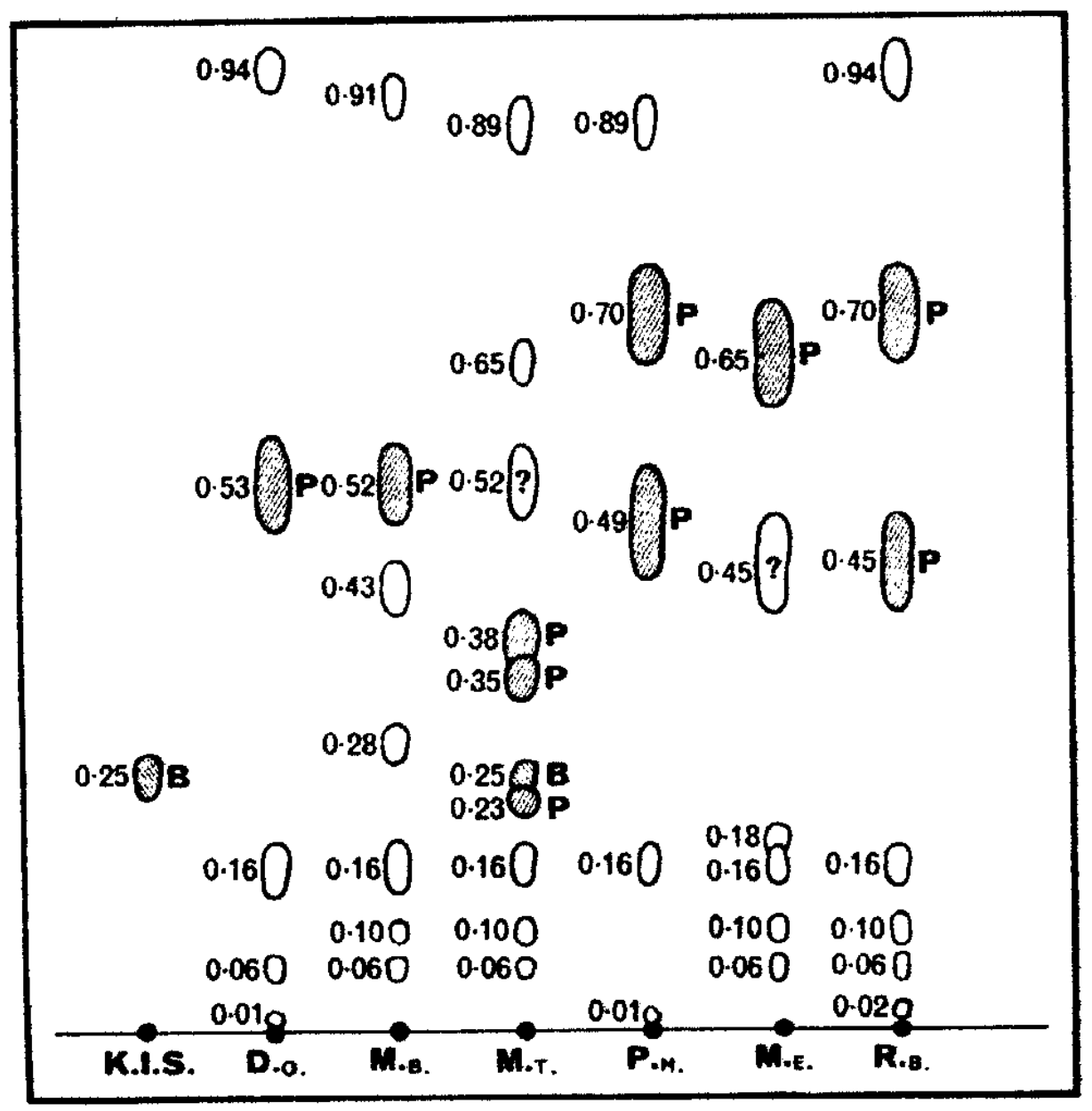

The precursors in Dicathais orbita and Murex brandaris are shown to be identical. For all these precursors, the first step in the reaction towards the purple is hydrolysis of the sulfate group with an enzyme (purpurase, arylsulfatase) leading to indoxyls. Indoxyls which lack a substituent in the 2position are then readily oxidised to give indigos. Those indoxyls which have substituents in the 2position are oxidised to indoleninones which dimerise to give the green photolabile tyriverdin. Tyriverdin was initially thought to be a quinhydrone type of compound, but later was shown to be a mixture of dimers. Photolysis of tyriverdin gives dibromoindigo and the long observed odorous dimethyl disulfide. The products from Murex trunculus are complex by reason of cross coupling of different indoxyls or indoleninones, eventually leading to indigo, indirubin, monobromoindigo and 
dibromoindigo and because there may be a variation in the composition depending on the gender of the animal or on the season $[107,108]$. The entire process of purple generation is shown in Figure 11. The recent suggestion [109] that leuco-dibromoindigo is the major precursor in the mollusc cannot be substantiated.

Figure 11. The generation of the purple.<smiles></smiles>

tyrindoxyl sulfate<smiles>CSc1[nH]c2cc(Br)ccc2c1O</smiles>

tyrindoxyl<smiles>C[C@]1([C@@]2(S)Nc3cc(Br)ccc3C2=O)Nc2cc(Br)ccc2C1=O</smiles>

tyriverdin<smiles>O=C1C(=O)N(c2ccc(Br)cc2)NC1=C1Nc2cc(Br)ccc2C1=O</smiles>

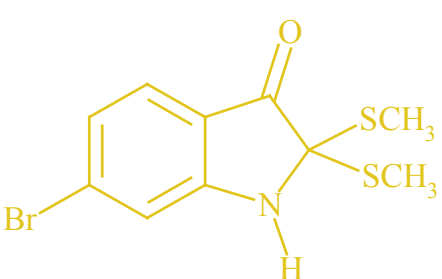

tyrindolinone

$\mathrm{O}_{2}$<smiles>[SiH3]C1=Nc2cc(Br)ccc2C1</smiles>

tyrindoleninone
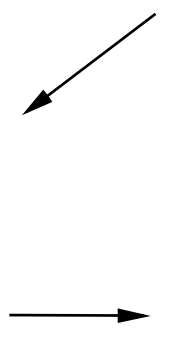

6,6'-dibromoindigo

6,6'-dibromoindirubin

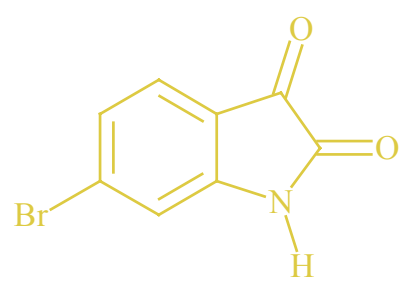

6-bromoisatin tyrindoxyl

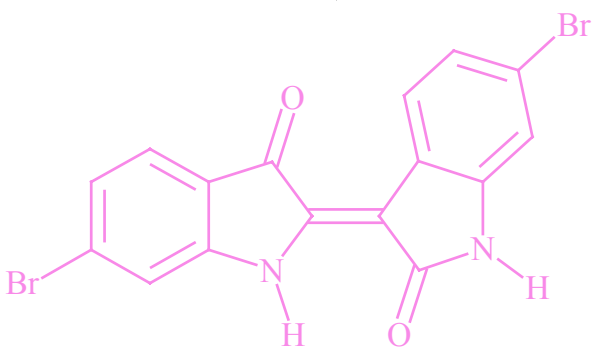




\section{(a) Tyrindoxyl sulfate}

Tyrindoxyl sulfate is the original source of the purple colour derived from molluscs. It is contained in the hypobranchial gland. The anion could be associated with one or more quaternary ammonium cations, e.g. $\beta, \beta$-dimethylacrylcholine $[110,111]$. When the gland is excised, an enzyme (purpurase) is released which removes the sulfate group to give tyrindoxyl. Tyrindoxyl sulfate can be isolated from the glands by extraction with ethanol if this is done before the enzyme has had time to act. Baker and Sutherland [41] describe how the live hypobranchial glands were extracted with ethanol and after evaporation the residue was dissolved in water.

Ion exchange chromatography using Amberlite CG-50 (H form) resin gave a fraction of $\mathrm{pH}$ 3-4 from which a silver salt could be isolated. The silver salt was converted using $\mathrm{KCl}$ into the potassium salt. Sodium tyrindoxyl sulfate could be chromatographed on Whatman No 1 paper using butanol acetic acid - water (78:5:17) giving a single spot at $\mathrm{R}_{\mathrm{f}} 0.56$ which could be visualised by UV light, spraying with the purpurase (sulfatase) enzyme or with $1 \mathrm{M}$ hydrochloric acid followed by heating to $100{ }^{\circ} \mathrm{C}$. The latter two processes eventually give after exposure to air and light purple spots.

NMR $\delta_{\mathrm{H}} 9.76 \mathrm{~s}(1 \mathrm{H}), 7.14 \mathrm{~m}(3 \mathrm{H}), 2.42 \mathrm{~s}(3 \mathrm{H})$ (from Dicathais orbita) [41]

(DMSO) 7.57d (8), 7.44d (2), 7.08dd (8,2), 2.44s (from Thais clavigera) [110]

\section{(b) Tyrindoxyl}

This is a transient compound formed from tyrindoxyl sulfate by enzymatic removal of the sulfate group. It is very readily oxidised by air but was probably observed by chromatography of the ether extracts of hypobranchial glands of several species.

Baker and Duke [112] examined Mancinella bufa, Mancinella keineri and Mancinella distinguenda in this way and showed that the products were identical to those of the previously investigated Dicathais orbita. Thus alumina chromatography with benzene showed, red and yellow spots at $R_{\mathrm{f}} 0.8$ and 0.5 which were oxidation products of tyrindoxyl, with tyrindoxyl itself giving a yellow spot at $R_{\mathrm{f}} 0.3$.

\section{(c) Tyrindoleninone and Tyrindolinone}

These intermediates are formed from tyrindoxyl by reaction with oxygen in the air. Tyrindoleninone is the primary product and some of it reacts with methane thiol to give tyrindolinone. Tyrindolinone readily loses methane thiol during chromatography and on heating to give tyrindoleninone. They are both readily detected by chromatography in a variety of species.

Tyrindoleninone has been identified as the pungent component of the edible Japanese Thais clavigera [115] and has been identified by GC in the egg masses of Australian and Mediterranean muricids [116] 
Table 6. $\mathrm{R}_{\mathrm{f}}$ data for TLC of tyrindoleninone and tyrindolinone.

\begin{tabular}{|l|l|l|l|l|}
\hline & \multicolumn{4}{|c|}{$\mathrm{R}_{\mathrm{f}}$ values } \\
\cline { 2 - 5 } & $\begin{array}{l}\text { Nucella } \\
\text { lapillus }^{\mathrm{a}}\end{array}$ & $\begin{array}{l}\text { Thais } \\
\text { clavigera }^{\mathrm{b}}\end{array}$ & $\begin{array}{l}\text { Dicathais } \\
\text { orbita }^{\mathrm{c}}\end{array}$ & $\begin{array}{l}\text { Dicathais } \\
\text { orbita }^{(\mathrm{eggs})}{ }^{\mathrm{d}}\end{array}$ \\
\hline Tyrindoleninone & 0.88 & 0.85 & 0.8 & 0.5 \\
\hline Tyrindolinone & 0.58 & 0.55 & 0.5 & 0.4 \\
\hline Tyriverdin & 0.32 & & 0.3 & \\
\hline
\end{tabular}

${ }^{a}$ Silicagel ${ }_{60}, 9: 1$ toluene-methanol [55]

${ }^{\mathrm{b}}$ Silicagel $60,9: 1$ toluene-methanol [113]

${ }^{c}$ Alumina, benzene [112]

${ }^{\mathrm{d}}$ Silicagel 60, 1:1 petrol - dichloromethane [114]

Tyrindoleninone: [112]

red needles, mp $109.5^{\circ} \mathrm{C}$

$\mathrm{NMR} \delta_{\mathrm{H}}\left(\mathrm{CCl}_{4}\right) 7.3 \mathrm{~m}(3 \mathrm{H}), 2.60 \mathrm{~s}(3 \mathrm{H}) ; \mathrm{NMR} \delta_{\mathrm{H}}\left(\mathrm{CDCl}_{3}\right) 7.3-7.4 \mathrm{~m}(3 \mathrm{H}), 2.65 \mathrm{~s}(3 \mathrm{H})[114]$

$\lambda_{\max }$ (hexane) (log $\left.\log _{10} \varepsilon\right) 217$ (3.94), 242 (4.40), 247 (4.40), 278 (4.04), 318 (3.72), 333 (3.70), 355

(3.43), $426(3.23), 447(3.23)$

MS m/z 257, 255, 242, 240, $133[112,114]$

Tyrindolinone: [112]

yellow needles, mp $117^{\circ} \mathrm{C}$

NMR $\delta_{\mathrm{H}}\left(\mathrm{CDCl}_{3}\right) 7.4 \mathrm{~m}(3 \mathrm{H}), 5.45 \mathrm{brs}(1 \mathrm{H}), 2.20 \mathrm{~s}(6 \mathrm{H})$

$\lambda_{\max }(\mathrm{EtOH})\left(\log _{10} \varepsilon\right) 225 \mathrm{sh}$ (4.32), 248 (4.40), 270sh (3.90), 355sh (3.20), 402 (3.43)

\section{(d) Tyriverdin}

This pale green solid is derived from the reaction of tyrindoxyl with tyrindoleninone. The most characteristic property is sensitivity to light when it gives the purple 6,6'-dibromoindigo and the highly odorous dimethyl disulfide. Being only slightly soluble in solvents, it is easily isolated and was observed in 1890 by Letellier [22]. Tyriverdin was initially thought [41] to have a quinhydrone structure. The solid darkens above $60{ }^{\circ} \mathrm{C}$ and gives a blue sublimate at $220^{\circ} \mathrm{C}$ without melting [41]. The dimeric structure, confirmed by synthesis (Figure 12a), was proposed by Christopherson [117] and later Fujise, Miwa and Ito [110] showed using ${ }^{1} \mathrm{H}-\mathrm{NMR}$ that two stereoisomers exist, one much more stable than the other. When a chloroform solution of tyriverdin is exposed to sunlight, dimethyl disulfide is released and 6,6'-dibromoindigo formed [41] along with 6-bromoisatin, depending on the amount of air present. Quantitative photochemical conversion to dibromoindigo has been observed [117] by IR in KBr. Although always described as green, the chemical structure would suggest it is yellow when pure. The absorption spectrum in methanol $\left(\lambda_{\max } 350,402 \mathrm{~nm}\right)$ also shows a maximum absorption at $598 \mathrm{~nm}$ which can be assigned to a trace of photodecomposition to give blue (in 
solution) 6,6'-dibromoindigo. The combination of yellow and blue colours gives green. Tyriverdin is highly bacteriostatic at $0.5 \mathrm{ppm}$ concentrations [114].

UV (MeOH) $\lambda_{\max } / \mathrm{nm}\left(\log _{10} \varepsilon\right) 237(4.37), 252(4.51), 275(4.08), 350(3.41), 402(3.46), 598(2.85)$ [110]

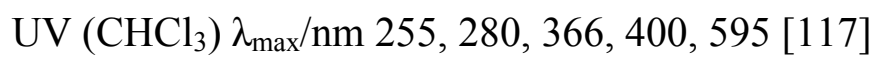

IR (KBr) $v_{\max } / \mathrm{cm}^{-1} 3380,1680,1600,1450,1310$ [117]; IR (KBr) $v_{\max } / \mathrm{cm}^{-1} 3387,1680,1448,1315$ [110]

${ }^{1} \mathrm{H}-\mathrm{NMR}$ (DMSO-d ${ }_{6}$ ) A $\delta_{\mathrm{H}} 8.22 \mathrm{brs}, 7.48 \mathrm{~d}(8), 7.31 \mathrm{~d}(1.8), 6.97 \mathrm{dd}(8,1.8), 1.88 \mathrm{~s}$ [110]; ${ }^{1} \mathrm{H}-\mathrm{NMR}$ (DMSO-d $\left.\mathrm{d}_{6}\right)$ B $\delta_{\mathrm{H}} 8.03 \mathrm{brs}, 7.33 \mathrm{~d}(8), 7.08 \mathrm{~d}(1.7), 6.89 \mathrm{dd}(8,1.7), 1.92 \mathrm{~s}[110] ;{ }^{1} \mathrm{H}-\mathrm{NMR}\left(\mathrm{DMSO} \mathrm{d}_{6}\right), \delta_{\mathrm{H}}$ 7.46 (8.4), 7.27(1.5), 6.96dd (8.4, 1.5), 1.90s [114]; ${ }^{1} \mathrm{H}-\mathrm{NMR}$ (DMSO-d $6,270 \mathrm{MHz}$ ), $\delta_{\mathrm{H}} 8.20 \mathrm{~s}, 7.47 \mathrm{~d}$ (8), 7.28d (1.5), 6.96dd $(8,1.5), 1.88 \mathrm{~s}[117]$

${ }^{13} \mathrm{C}$ NMR $\left(\right.$ DMSO-d $\left._{6}\right) \delta_{\mathrm{C}} 195.5,159.9,125.6,121.5,118.0,114.5,72.7,11.6[110]$

Figure 12. The synthesis of the intermediates of the purple and the minor components.

(a) Tyriverdin [117]<smiles>CN1C(=C2Nc3cc(Br)ccc3C2=O)C(=O)c2ccc(Br)cc21</smiles><smiles>[2H]N1c2cc(Br)ccc2C(=O)[C@@]1(O)[C@]1([2H])Nc2cc(Br)ccc2C1=O</smiles><smiles>C[C@@]1([C@@]2(C)Nc3cc(Br)ccc3C2=O)[CH]Nc2cc(Br)ccc2C1=O</smiles>

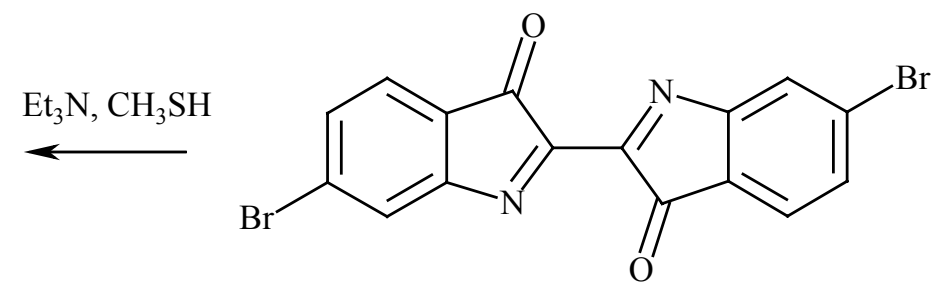

(b) 6-Bromoisatin [118]<smiles>Nc1cccc(Br)c1</smiles><smiles>O=CC(=O)Nc1cccc(Br)c1</smiles><smiles>O=C1Nc2cc(Br)ccc2C1=O</smiles> 
(c) 6-Bromoindigo [75]<smiles>O=C1Nc2cc(Br)ccc2C1=O</smiles><smiles>COc1cn(I)c2ccccc12</smiles><smiles>O=C1C(=C2Nc3cc(Br)ccc3C2=O)Nc2ccccc21</smiles>

(d) 6,6'-Dibromoindirubin [54]<smiles>O=C1Nc2cc(Br)ccc2C1=O</smiles><smiles>CC(=O)Oc1c[nH]c2cc(Br)ccc12</smiles>

$\mathrm{Na}_{2} \mathrm{CO}_{3}, \mathrm{CH}_{3} \mathrm{OH}$<smiles>O=C1Nc2cc(Br)ccc2/C1=C1/Nc2cc(Br)ccc2C1=O</smiles>

\section{The minor components in the purple}

(a) 6-Bromoisatin

This yellow material, unconnected with the purple colour, has been reported as one of the products found from the autolysed hypobranchial glands of many molluscs and has been known for a long time. It was mentioned by Schunck [23] in 1879 and Letellier [22] in 1890. It could originate from the oxidative photolysis of tyriverdin [41], tyrindoxyl sulfate [104, 105] or hydrolysis of tyrindolinone [55]. 6-Bromoisatin may be the precursor of 6,6'-dibromoindirubin which is nearly always associated with dibromoindigo of marine origin. It is readily synthesised (see Figure 12b) from 3-bromoaniline by the Marvel and Hiers (1941) modification of the Sandmeyer reaction (1919) followed by a pHbased separation procedure from the 4-isomer [118]. 
$\operatorname{Mp} 270{ }^{\circ} \mathrm{C}[118] ; 273-274{ }^{\circ} \mathrm{C}[41]$

${ }^{1} \mathrm{H}-\mathrm{NMR}\left(\mathrm{DMSO}_{-} \mathrm{d}_{6}\right), \delta_{\mathrm{H}} 11.15 \mathrm{brs}, 7.42 \mathrm{~d}(7.9), 7.24 \mathrm{dd}(8.0,1.6), 7.06 \mathrm{~d}(1.6)[75]$

(b) 6-Bromoindigo

This compound is found to some extent in all the Tyrian purple samples. The origin is uncertain, but it seems likely that it comes from oxidation of leuco-bromoindigo which is derived from leucodibromoindigo by photodebromination. The synthesis and properties have been described [75]. 6Bromoisatin is reacted with $\mathrm{PCl}_{5}$ in chlorobenzene and then 3-acetoxyindole added. The use of chlorobenzene as a solvent is dictated by the need for a higher reaction temperature than can be achieved in benzene [120] and for an inert solvent. The product is filtered and recrystallised from ethyl benzoate to give black crystals with a copper lustre in moderate $(20 \%)$ yield. This reaction seems generally applicable to monobromoindigos. The synthesis is illustrated in Figure 12c. When used to dye wool, the colour is blue at low concentration and purple at high concentration, which appears to mirror the behaviour of dibromoindigo on silk.

$\lambda_{\max }$ (tetrachloroethane)/nm 601 [75]; $\lambda_{\max }($ reflectance) $/ \mathrm{nm} 521$

MS m/z 342 (100), 340 (100), 314 (14), 312 (14), 262 (5), 233 (9), 205 (28)

${ }^{1} \mathrm{H}-\mathrm{NMR}\left(\mathrm{N}, \mathrm{N}\right.$-bistrifluoroacetyl derivative, $\mathrm{CDCl}_{3}$ ), $\delta_{\mathrm{H}} 8.30 \mathrm{~d}(1.2), 8.06 \mathrm{~d}(8.4) 7.95 \mathrm{~d}(7.7), 7.79 \mathrm{td}$ (7.4, 1.3), 7.75d (8.1), 7.56dd (8.1, 1.4), 7.42t (7.4)

IR (KBr) $v_{\max } / \mathrm{cm}^{-1} 3271,1610,1609,1608$

(c) 6,6'-Dibromoindirubin

Indirubins are invariably prepared by reacting isatins with indoxyls. 6,6'-Dibromoindirubin ( $0-14 \%$ in Tyrian purple, Table 3) is probably derived from 6-bromoisatin (Figure 11). The suggestion that the origin is isomerisation of dibromoindigo [121] in unlikely. 6,6'-Dibromoindirubin was first synthesised by Ettinger and Friedlander [122] in 1912 by reacting 6-bromoisatin with 6-bromo-1acetyl-3-acetoxyindole in acetic acid containing $10 \% \mathrm{HCl}$. Fouquet [105] achieved $34 \%$ yield by using the same route, and Clark and Cooksey [54] obtained 76\% yield from 6-bromoisatin and 6-bromo-3acetoxyindole in methanol with $\mathrm{Na}_{2} \mathrm{CO}_{3}$. The product was obtained as fine brown needles which gave a purple colour in solution.

$\lambda_{\max }\left(\mathrm{CHCl}_{3}\right)\left(\log _{10} \varepsilon\right) 552$ (4.07), 525, 387sh, 367 (3.94), 350sh, 305 (4.43) [105]; $\lambda_{\max }$ (xylene) 567, 520sh [122]; (tetrachloroethane) ( $\left.\log _{10} \varepsilon\right) 552$ (3.89), 371 (3.73), 305 (4.28) [54]

${ }^{1} \mathrm{H}-\mathrm{NMR}$ (DMSO-d $\mathrm{d}_{6}$ ), $\delta_{\mathrm{H}} 11.2 \mathrm{brs}, 11.1 \mathrm{brs}, 8.67 \mathrm{~d}(8.5), 7.68 \mathrm{~d}$ (1.6), 7.62d (8.1), 7.22dd (8.5, 1.7), $7.20 \mathrm{dd}(7.9,1.6), 7.05 \mathrm{~d}(1.8)[54]$

MS m/z 422 (47), 420 (100), 418 (43), 394 (4), 392 (8), 390 (5), 314 (14), 312 (10), 285 (16), 283 (13) [54]

IR (KBr) $v_{\max } / \mathrm{cm}^{-1} 3325,3164,1672,1586,963,909,824,815,770[54]$ 


\section{Chemical properties of 6,6 '-Dibromoindigo}

In the solid state the purple dye is remarkably stable. Ozone is known [123] to cleave it to give 6bromoisatin and 6-bromoisatoic anhydride. In solution, indigo is quite reactive to oxygen, giving isatin, but 6,6'-dibromoindigo is less soluble and this oxidation reaction is less important. More powerful chemical oxidants (e.g., dichromate) will cleave 6,6'-dibromoindigo to give 6-bromoisatin [124].

Figure 13. The reduction of indigos to leucoindigos and the photodebromination of leucoindigos.<smiles>O=C1/C(=C2\Nc3cc(Br)ccc3C2=O)Nc2cc(Br)ccc21</smiles>

dibromoindigo (purple)<smiles>O=C1C(=C2Nc3cc(Br)ccc3C2=O)Nc2ccccc21</smiles>

monobromoindigo (purple/blue)<smiles></smiles>

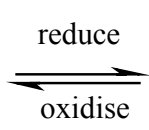

$\underset{\text { oxidise }}{\stackrel{\text { reduce }}{\rightleftharpoons}}$<smiles>[O-]c1c(-c2[nH]c3cc(Br)ccc3c2[O-])[nH]c2cc(Br)ccc12</smiles>

leuco-dibromoindigo<smiles>[O-]c1c(-c2[nH]c3cc(Br)ccc3c2[O-])[nH]c2ccccc12</smiles>

leuco-monobromoindigo<smiles>[O-]c1c(-c2[nH]c3ccccc3c2[O-])[nH]c2ccccc12</smiles>

leuco-indigo

In the same way as indigo, 6,6'-dibromoindigo can be reduced to a water soluble yellow leucocompound either chemically (e.g., with sodium dithionite) or biochemically [19]. Leuco-6,6'dibromoindigo is unstable in light, UV or sunlight, readily losing one or two bromine atoms to give leuco-bromoindigo or leuco-indigo. Oxidation of these leuco compounds in the air restores the corresponding indigo compound. The reactions are shown in Figure 13. This photodebromination has long been observed [38,39], is the basis for a qualitative identification of dibromoindigo [1], and has been used to synthesise deuterated indigos from the corresponding halo-derivatives [125]. 


\section{Further information}

The literature about dibromoindigo is extensive and wide-ranging. Several bibliographies have been published, notably by Bruin (1966, [40]), Schweppe (1993, [126]), Spanier (1982, [127]) and Cooksey (1993, [128]). Most writers on the purple give a resumé of past publications and useful summaries are given by Baker (1974, [83]), Cardon (1990, [129]), Michel and McGovern (1987, 1990, [10,11]), Clark (1993, [130]), and for Japanese language readers Fujisi (1999, [115]). For the Jewish connection, consult Spanier (1987, [131]).

In 1859, Henri Lacaze-Duthiers wrote [26, 132]

A quel usage pourrait-on employer la pourpre? Aujourd'hui que les manufactures de produits chimiques versent à torrent dans l'industrie des matières qui, avec la plus grande facilité et la plus grandes perfection, peuvent servir aux teintures les plus delicates et les plus riches, comment pourrait-on espérer de voir ce peu de matières animale donnant du violet, quoique fort beau et fort tenace, être employé par l'industrie? Il n'est guère probable que la pourpre revienne en honneur.

But there is considerable interest. In Mexico in 1909 [29], a traditional purple skirt de caracolillo would cost 10 dollars gold. Recently [133] the Tyrian purple pigment (from Nucella lapillus) become available at $58.50 \mathrm{GBP}$ for $25 \mathrm{mg}$, rather more than the $10-20$ times the price of gold it was in Roman times [9]. Chemical synthesis should be able to afford a viable alternative to harvesting mollusks.

The author investigates Murex trunculus, January 2001

Photo: Rolf Haubrichs, Geneva.

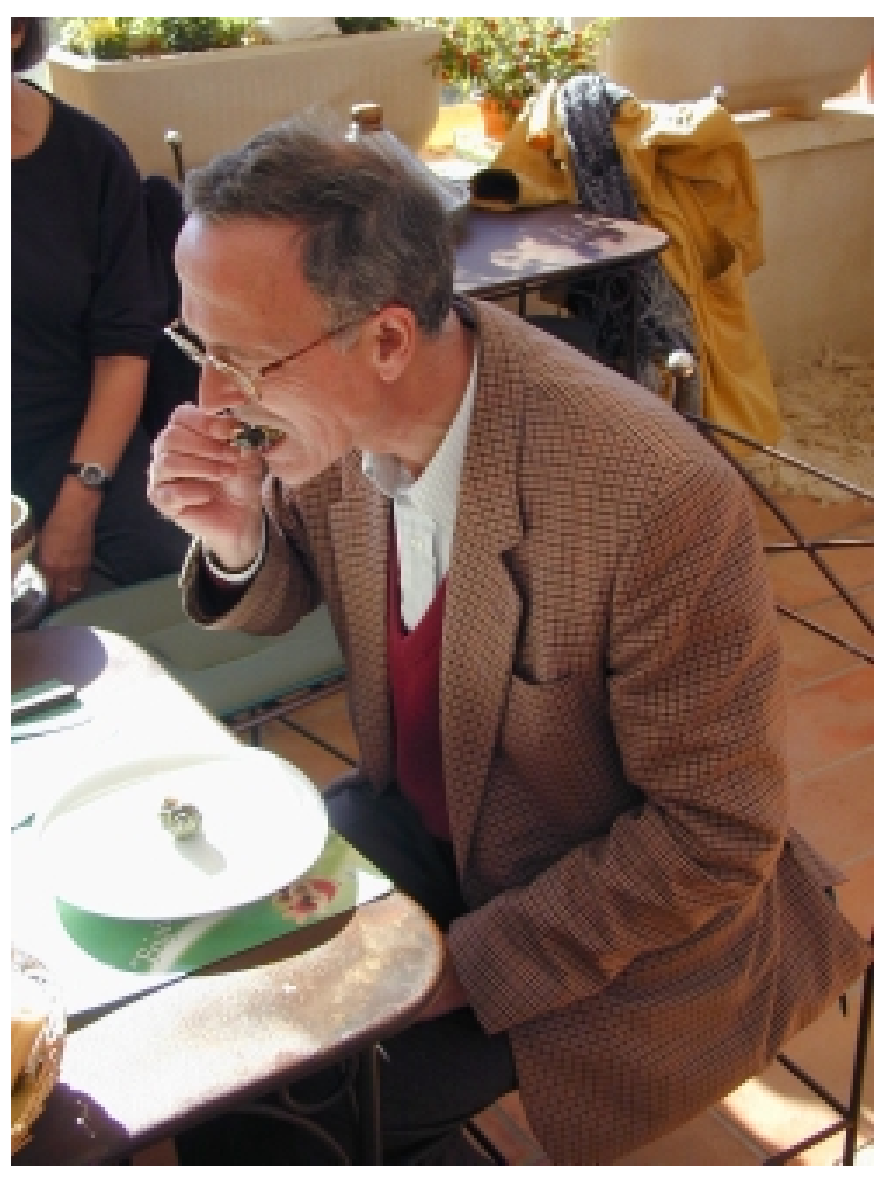




\section{References and Notes}

1. McGovern, P.E.; Michel, R.H. Royal Purple dye: tracing the chemical origins of the industry, Anal. Chem. 1985, 57, 1514A-1522A.

2. Jackson, J.W. The Geographical Distribution of the Shell-Purple Industry, Longmans, Green and Co: London, 1917, 1-29.

3. Pliny the Elder. Historia Naturalis, book IX, sections $60-65$, chs. XXXVI-XLI as translated by Bailey, 1929.

4. Cole, W. Purple Fish, Phil. Trans. Roy. Soc. 1685, 15, 1278-1286.

5. Reinhold, M. The history of purple as a status symbol in antiquity, Collect. Latomus. 1970, 116, $1-73$.

6. Dedekind, A. Ein Beitrag zur Purpurkunde, Berlin, Vol 1 1898, 364 pp; Vol 2 1906, 379 pp, vol 3 1908, 785 pp, vol 4 1911, 848 pp.

7. Becker, C. Did the people in Ayios Mamas produce purple-dye during the Middle Bronze Age? Considerations on the prehistoric production of purple-dye in the Mediterranean, Animals and Man in the Past, ARC-Publicatie: Groningen, the Netherlands, 2001, 121-134.

8. Born, W. Purpura Shell-Fish, Ciba Rev. 1937, 1, 106-110.

9. Born, W. Purple in Classical Antiquity, Ciba Rev. 1937, 1, 111-118.

10. Michel, R.H.; McGovern, P.E. The chemical processing of Royal Purple dye: ancient descriptions as elucidated by modern science, Archeomaterials. 1987, 1, 135-143.

11. Michel, R.H.; McGovern, P.E. The chemical processing of Royal Purple dye: ancient descriptions as elucidated by modern science, part II, Archeomaterials. 1990, 4, 97-104.

12. Doumet, J. Étude sur la couleur pourpre ancienne et tentative de reproduction du procédé de teinture de la ville de Tyr décrit par Pline l'Ancien, Imprimerie Catholique: Beirut, 1980.

13. Cheek, G.T.; Barthel, R.V. Electrochemical studies of indigoid systems, Proc. - Electrochem. Soc. 93-11(Proceedings of the Fifth International Symposium on Redox Mechanisms and Interfacial Properties of Molecules of Biological Importance, 1993), 1993, 165-74.

14. Elsner, O.; Spanier, E. Dyeing with Murex extracts, an unusual dyeing method of wool to the Biblical sky blue, Proc. Int. Wool Text. Res. Conf., $7^{\text {th }}$. 1985, 5, 118-130.

15. Padden, A.N.; John, P.; Collins, M.D.; Hutson, R.; Hall, A.R. Indigo-reducing Clostridium isatidis isolated from a variety of sources, including a tenth century Viking woad vat, $J$. Archaeol. Sci. 2000, 27, 953-956.

16. Padden, A.N.; Dillon, V.M.; Edmonds, J.; Collins, M.D.; Alvarez, N.; John, P. An indigoreducing moderate thermophile from a woad vat, Clostridium isatidis sp. nov., Int. J. Syst. Bacteriol. 1999, 49, 1025-1031.

17. Padden, A.N.; Dillon, V.M.; John, P.; Edmonds, J.; Collins, M.D.; Alvarez, N. Clostridium used in mediaeval dyeing, Nature. 1998, 396, 225.

18. Purple snail meeting, Rousillon, January 2001.

19. Edmonds, J. Tyrian or Imperial purple dye, Historic Dye Series No 7, ISBN 09534133 65. 2000, $41 \mathrm{pp}$. 
20. Verhecken, A. Experiments with the dyes from European purple-producing shellfish, Dyes Hist. Archaeol. 1994, 12, 32-35.

21. Verhecken, A. Experiences with mollusc purple, La Conchiglia, 1990, 22, 250-252.

22. Letellier, A. Recherches sur la pourpre produite par le Purpura lapillus, Archiv. Zool. exper. et gen (2). 1890, 8, 361 .

23. Schunck, E. Notes on the Purple of the Ancients. 1. The Chromogen of Purpura Capillus. 2. Properties of the Colouring Matter formed by Insolation from the Chromogen of Purpura Capillus, J. Chem. Soc. 1879, 35, 589-596.

24. Réaumur, R.A. F. de. Mém. Acad. Roy. Sci. Amsterdam, 1711, 168.

25. Duhamel, H.L. Mém. Acad. Roy. Sci. Paris, 1736.

26. Lacaze-Duthiers, H. Mémoire sur le Pourpre, Mém. Soc. Imp. Sci. Agricult. Arts Lille, 1859, 2éme Serie, 6, 303-380.

27. Juan, Don Jorge; de Ulloa, Don Antonio. Relación Historica del viage a la America Meridional, Madrid, 1748, book 4, pp. 242-244.

28. Squier, E. G. Nicaragua: its people, scenery, monuments, and the proposed interoceanic canal, with numerous original maps and illustrations, New York, 1852, vol 1, p. 286, quoted by Schunck E 1880 [35].

29. Nuttall, Z. A Curious survival in Mexico of the use of the Purpura Shell-fish for dyeing, Putnam Anniversary Volume, The Torch Press: Cedar Rapids, Iowa, 1909, 366-384.

30. Thompson, J. Shellfish Purple: The Use of Purpura patula pansa on the Pacific Coast of Mexico, Dyes Hist. Archaeol. 1995, 13, 3-6.

31. Rios-Jara, E.; León, H.G; Lizárraga-Chávez, L.; Michel-Morfín, J.E. Producción y tiempo de recuperación del tinte de Plicopurpura patula pansa (Neogastropoda: Muricidae) en Jalisco, México, Rev Biol. Trop. 1994, 42, 537-545.

32. Michel-Morfin, J.E.; Chavez, E.A. Effect of repetitive dye extraction over yield and survival rate of the purple snail Plicopurpura pansa (Gould, 1853), J. Shellfish Res. 2000, 19, 913-917.

33. Michel-Morfin, J.E, Chavez, E.A.; Landa, V, Population parameters and dye yield of the purple snail Plicopurpura pansa (Gould, 1853) of west central Mexico, J. Shellfish Res. 2000, 19, 919925.

34. Bizio, B. Scoperta del principio purpureo nei due Murex brandaris e trunculus Lina., e studio delle sue proprietà, Ann. Sci. Lombardo-Veneto, 1833, 346-364.

35. Schunck, E. Notes on the Purple of the Ancients. 3. Purple dyeing in modern times, J. Chem. Soc. 1880, 613-617.

36. Friedlander, P. Uber den Farbstoff des antiken Purpurs aus murex brandaris, Ber. Dtsch. Chem. Ges. 1909, 42, 765-770.

37. Friedlander, P. Uber die Farbstoffe aus Purpura aperta and Purpura lapillus, Ber. Dtsch. Chem. Ges. 1922, 55, 1656-1658.

38. Driessen, L.A. Über eine charakteristische Reaktion des antiken Purpurs auf der Faser, Melliand Textilber. 1944, 25, 66. 
39. Van Alphen, J. Remarks on the Action of Light on Indigo Dyes in a Reducing Medium, Rec. Trav. Chim. Pays Bas, 1944, 63, 95-96.

40. Bruin, F. Royal Purple and the dye industries of the Mycenaeans and Phoenicians, Sociétés et Compagnies de Commerce en Orient et dans l'Océan Indien (Acts du huitième colloque international d'histoire maritime, Beyrouth - 5-10 Septembre 1966), 1966, 73-90.

41. Baker, J.T.; Sutherland, M.D. Pigments of marine animals VIII. Precursors of 6,6'-Dibromoindigotin (Tyrian Purple) from the mollusc Dicathais Orbita Gmelin, Tetrahedron Lett. 1968, 4346.

42. Sasaki, K. Chemical structure of ancient purple dye. Tyrian purple. Senryo To Yakuhin, 1975, 20, 36-45.

43. Gibaja Oviedo, S.; Salazar de Cavero, L. Production of Tyrian purple from the Concholepas mollusk "Chanque", Bol. Soc. Quim. Peru, 1977, 43, 139-40.

44. Taylor, G.W.Detection of shellfish purples on textiles, Dyes Hist. Archaeol. 1983, 2.

45. McGovern, P.E.; Michel, R.H. Royal Purple dye: tracing the chemical origins of the industry, Anal. Chem. 1985, 57, pp1514A-1522A.

46. Daniels, V. Dye analysis of two fragments from Enkomi, Dyes Hist. Archaeol. 1985, 4, 15-18.

47. Daniels, V. Further work on the dye analysis of textile fragments from Enkomi, Dyes Hist. Archaeol. 1987, 6, 3-7.

48. McGovern, P.E.; Lazar, J.; Michel, R.H. The analysis of indigoid dyes by mass spectrometry, $J$. Soc. Dyers Colour. 1990, 106, 22-25.

49. McGovern, P.E.; Lazar, J.; Michel, R.H. Caveats on the analysis of indigoid dyes by mass spectrometry, J. Soc. Dyers Colour. 1991, 107, 280-281.

50. Wouters, J. A new method for the analysis of blue and purple dyes in textiles, Dyes Hist. Archaeol. 1992, 10, 17-21.

51. Koren, Z.C. High-performance Liquid Chromatographic Analysis of an Ancient Tyrian Purple Dyeing Vat from Israel, Isr. J. Chem. 1995, 35, 117-124.

52. Kosugi, Y.; Matsumoto, K.A. convenient and rapid detection method of Kaimurasaki coloring matter by MS, Bunseki Kagaku. 1994, 43, 1133-1136.

53. Shimoyama, S.; Noda, Y. Non-destructive three-dimensional fluorescence technique, Dyes Hist. Archaeol. 1994, 12, 50-61.

54. Clark, R.J.H.; Cooksey, C.J. Bromoindirubins: the synthesis and properties of minor components of Tyrian purple and the composition of the colorant from Nucella lapillus, J. Soc. Dyers Colour. 1997, 113, 316-321.

55. Cooksey, C.J.; Withnall, R. Chemical studies on Nucella lapillus, Dyes Hist. Archaeol. Lyon 1997 (in press).

56. Shimoyama, S. Studies on the non-destructive determination of dyestuffs used in ancient colored cloths and ukiyo-e prints by the three-dimensional display of fluorescence spectra, Bunseki Kagaku, 1999, 48, 951-952.

57. Withnall, R.; Patel, D.; Cooksey, C.J.; Naegel, L. Chemical Studies of the Purple Dye of Purpura pansa, Dyes Hist. Archaeol. Edinburgh 2000 (in press). 
58. Sachs, F.; Kempf, R. Uber p-Halogen-o-nitrobenzaldehyde, Ber. Dtsch. Chem. Ges. 1903, 36, 3299-3303.

59. Baeyer, A.; Drewson, V. Darstellung von Indigblau aus Orthonitrobenzaldehyd, Ber. Dtsch. Chem. Ges. 1882, 2856-2864.

60. Sachs, F.; Sichel, E. Ueber p-substituirte o-Nitrobenzaldehyde, Ber. Dtsch. Chem. Ges. 1904, 37, 1861-1874.

61. Grandmougin, E.; Seyder, P. Uber Indigo. V:Uber halogenierte Indigo und Derivate, Ber. Dtsch. Chem. Ges. 1914, 47, 2365-2373.

62. Harley-Mason, J. A new synthesis of indigo, J. Chem. Soc. 1950, 2907.

63. Barber, H.J.; Stickings, C.E. Phenanthrene-3:6-diamidine, J. Chem. Soc. 1945, 167-169.

64. Pinkney, J.M.; Chambers, J.A. Synthesising Tyrian purple, Educ. Chem. 1979, 16, 144-145.

65. Torimoto, N.; Morimoto, S.; Shingaki, T. Synthesis of Tyrian Purple as a teaching material, Kagaku to Kyoiku. 1991, 39, 198-201.

66. Voss, G.; Gerlach, H. Regioselektiver Brom/Lithium-Austausch bei 2,5-Dibrom-1-nitrobenzol. Eine einfache Synthese von 4-Brom-2-nitrobenzaldehyde und 6,6'-Dibromindigo, Chem. Ber. 1989, 122, 1199-1201.

67. Cooksey, C.J. unpublished observation.

68. Kröhnke, F. Neuere Methoden der preparativen organischen Chemie. Synthesen mit Hilfe von Pyridiniumsaltzen (IV), Angew. Chem. 1963, 75, 317-329.

69. Cooksey, C.J. Making Tyrian purple, Dyes Hist. Archaeol. 1995, 13, 7-13.

70. Lüttke, W.; Klessinger, M. Theoretische und spektroskopische Untersuchungen an Indigofarbstoffen, I. Infrarot- und Lichtabsorptionsspektren einfacher Indigofarbstoffe, Chem. Ber. 1964, 97, 150-163.

71. Lüttke, W.; Klessinger, M. Theoretische und spektroskopische Untersuchungen an Indigofarbstoffen, II. Das Chromophore System der Indigofarbstoffe, Tetrahedron, 1963, 19 (Suppl. 2), 315-335.

72. Serrano-Andrés, L.; Roos, B.O. A theoretical study of the indigoid dyes and their chromophore, Chem.-Eur. J. 1997, 3, 717-725.

73. Friedländer, P.; Bruckner, S.; Deutsch, G. Über Brom- und Methoxyderivate des Indigos, Ann. Chem. 1912, 388, pp. 23-49.

74. Formanek, J. Über den Einfluß verschiedener Substituenten auf Farbe und Absorptions Spektrum des Indigo, Thioindigo und Indirubin, Z. Angew. Chem. 1928, 41, 1133-1141.

75. Clark, R.J.H.; Cooksey, C.J. Monobromoindigos: a new general synthesis, the characterization of all four isomers and an investigation into the purple colour of 6,6'-dibromoindigo, New $\mathrm{J}$. Chem. 1999, 23, 323-328.

76. Sadler, P.W. Absorption Spectra of Indigoid Dyes, J. Org. Chem. 1956, 21, 316-318.

77. Brode, W.R.; Pearson, E.G.; Wyman, G M. The Relation between the Absorption Spectra and the Chemical Constitution of Dyes. XXVII. cis-trans Isomerism and Hydrogen Bonding in Indigo Dyes, J. Am. Chem. Soc. 1954, 76, 1034-1036. 
78. Miliani, C.; Romani, A.; Favaro, G.A. Spectrophotometric and fluorimetric study of some anthraquinoid and indigoid colorants used in artistic paintings, Spectrochim. Acta Ser A, 1998, $54,581-588$.

79. Shen, B.; Olbrich-Stock, M.; Posdorfer, J.; Schindler, R.N. An Optical and Spectroelectrochemical Investigation of Indigo Carmine, Z. Phys. Chem. 1991, 173, 251-255.

80. José-Yacamán, M.; Rendón, L.; Arenas, J.; Puche, M.C.S. Maya Blue Paint: An Ancient Nanostructured Material, Science, 1996, 273, 223-225.

81. Kleber, R.; Masschelein-Kleiner, L.; Thissen, J. Étude et Identification du 'Bleu Maya', Stud. Conserv. 1967, 12, 41-56.

82. Artioli, G.; Galli, E.; Burattini, E.; Cappuccio, G.; Simeoni, S. Palygorskite from Bolca, Italy - A Characterization by High-Resolution Synchrotron-Radiation Powder Diffraction and Computer Modeling, Neues Jahrb. Mineral.,Monatsh. 1994, 217-219.

83. Cooksey, C.J. unpublished observation.

84. Baker, J.T. Tyrian purple. Ancient dye, a modern problem, Endeavour, 1974, 33 , 11-17.

85. Tatsch, E.; Schrader, B. Near-Infrared Fourier Transform Raman Spectroscopy of Indigoids, $J$. Raman Spectr. 1995, 26, 467-473.

86. Jackson, A.H.; Jenkins, R.T.; Grinstein, M.; Ferramola de Sancovich, A-M.; Sancovich, H.A. The isolation and identification of indigoid pigments from urine, Clin. Chim. Acta, 1988, 172, 245-252.

87. Voss, G. The analysis of indigoid dyes as leuco forms by NMR spectroscopy, J. Soc. Dyers Colour. 2000, 116, 80-90.

88. Withnall, R.; Clark, R.J.H.; Cooksey, C.J.; Daniels, M.A.M. Non-destructive, in situ identification of indigo/woad and shellfish purple by Raman microscopy and visible reflectance spectroscopy, Dyes Hist. Archaeol. 1993, 11, 19-24.

89. Clark, R.J.H.; Cooksey, C.J.; Daniels, M.A.M.; Withnall, R. Indigo - red white and blue, Educ. Chem. 1996, 16-19.

90. Gibbs, P.J.; Jordan, G.J.; Sedden, K.R.; Cooksey, C.J.; Brovenko, N.M.; Tiomkin, E.N.; Petrosyan, Y.A.. The in situ identification of indigo on ancient papers, Eur. Mass Spectrom. 1995, 1, 417-421.

91. Golding, B.T.; Pierpoint, C. Indigo blue, Educ. Chem. 1986, 71-73.

92. Posner, T. Beiträge zur Kenntnis der Indigo-Gruppe, VI: Über die Einwirkung von Säurechloriden auf Indigo und Indigo-Derivate, sowie über die Raumformel des Indigos, Ber. Dtsch. Chem. Ges. 1926, 59, 1799-1833.

93. von Eller, H. Stéréochemie de l'indigo dans l'etat cristallin, C. R. Hebd. Seances Acad. Sci. 1954, 239, 975-976.

94. Süsse, P.; Krampe, C. 6,6'-Dibromo-indigo, a main component of Tyrian purple. Its crystal structure and light absorption, Naturwissenschaften, 1979, 66, 110.

95. Larsen, S.; Watjen, F. The crystal and molecular structures of tyrian purple (6,6'dibromoindigotin) and 2,2'-dimethoxyindigotin, Acta Chem. Scand. Ser. A, 1980, A34, 171-176.

96. Süsse, P.; Steins, M.; Kupcik, V. Z. Kristallogr. 1988, 184, 269. 
97. Wouters, J.; Verhecken, A. Composition of Murex dyes, J. Soc. Dyers Colour. 1992, 108, 404.

98. Cooksey, C.J.; Withnall, R. Chemical studies on Nucella lapillus, Dyes Hist. Archaeol. Lyon 1997 (in press).

99. Wouters, J. personal communication.

100. Bide, M.J.; Choi, H. The thin layer chromatography of vat dyes, J. Soc. Dyers Colour. 1992, 108, 133-138.

101. Cooksey, C.J. TLC of the Indigoid Colorants in Shellfish Purple, Dyes Hist. Archaeol. 1996, 14, 70-77.

102. Bouchilloux, S.; Roche, J. Sur la pourpre des Murex trunculus et ses précurseurs, C. R. Soc. Biol. Lyon, 1954, 148, 1583-1587.

103. Bouchilloux, S.; Roche, J. Sur les prochromogenes et les pigments purpuriques de Murex trunculus Linné, C. R. Soc. Biol., Lyon. 1954, 148, 1732-1734.

104. Malaszkiewicz, J. Chromogene und Farbstoff-Komponenten der Purpurschnicke Murex trunculus, Ph.D.Thesis, University of Saarbrücken, Saarbrücken, 1967.

105. Fouquet, H. Bau und Reaktionen natürlicher Chromogene indigoider Farbstoffe bei Purpurschnecken, Ph.D. Thesis. University of Saarbrücken, Saarbrücken, 1970.

106. Fouquet, H.; Bielig, H.J. Biological Precursors and Genesis of Tyrian Purple, Angew Chem (Int Edit), 1971, 10, 816-817; Fouquet, H.; Bielig, H.J. Biologische Vorstufen und Genese von antikem Purpur, Angew Chem, 1971, 83, 856-857.

107. Spanier, E. Rediscovering Royal Purple and Biblical Blue, Oceanus, 1990, 33, 75.

108. Michel, R.H.; Lazar, J.; McGovern, P.E. The chemical composition of the indigoid dyes derived from the hypobranchial glandular secretions of Murex molluscs, J. Soc. Dyers Colour. 1992, $108,145-150$.

109. Melzer, R.R.; Brandhuber, P.; Zimmermann, T.; Smola, U. Der Purpur: Farben aus dem Meer, Biol. Unserer Zeit. 2001, 31, 30-39.

110. Fujise, Y.; Miwa, K.; Ito, S. Structure of tyriverdin, the intermediate precursor of Tyrian purple, Chem. Lett. 1980, 6, 631-632.

111. Baker, J.T.; Duke, C.C. Isolation of Choline and Choline ester salts of Tyrindoxyl sulfate, Tetrahedron Lett. 1976, 1233-1234.

112. Baker, J.T.; Duke, C.C. The Chemistry of the indoleninones. II. Isolation from the hypobranchial glands of marine molluses of 6-bromo-2,2-dimethylthioindolin-3-one and 6-bromo-2methylthioindoleninone as alternative precursors to Tyrian Purple, Aust. J. Chem. 1973, 26, 2153-2157.

113. Hiyoshi, Y.; Fujise, Y. Tyrian purple. As a learning tool for natural product chemistry, Kagaku to Kyoiku, 1992, 40, 390-3.

114. Benkendorff, K.; Bremner, J.B.; Davis, A.R. Tyrian purple precursors in the egg masses of the Australian muricid, Dicathais orbita: A possible defensive role, J. Chem. Ecol. 2000, 26, 10371050.

115. Fujise, Y. Chemistry of the Production of Tyrian Purple and Related Natural Products, Kagakushi, 1999, 26, 34-44. 
116. Benkendorff, K.; Bremner, J.B.; Davis, A.R. Indole derivatives from the egg masses of Muricid molluscs, Molecules, 2001, 6, 70-78.

117. Christophersen, C.; Wätjen, F.; Buchardt, O.; Anthoni, U. A revised structure of tyriverdin. The precursor of Tyrian purple, Tetrahedron, 1978, 34, 2779-81.

118. Sadler, P.W. J. Org. Chem. 1956, 21, 169-70.

119. Holt, S.J.; Sadler, P.W. Studies in enzyme cytochemistry. II. Synthesis of indigogenic substrates for esterases, Proc. Roy. Soc. London, B. 1958, 148, 481-494.

120. Baker, J.T.; Duke, C.C. The Chemistry of the indoleninones. III. Reactions of 2(Methylthio)indoleninones with Diazomethane, Aust. J. Chem. 1976, 29, 1023-1030.

121. Imming, P.; Zentgraf, M.; Imhof, I. Welche Farbe hatte der antike Purpur?, Textilveredlung, 2000, 35, 22-24.

122. Ettinger, L.; Friedlander, P. Uber 6,6'-dibrom-indirubin, Ber. Dtsch. Chem. Ges. 1912, 45, 20812083.

123. Grosjean, D.; Sensharma, D.K.; Cass, G.R. Fading of colorants by atmospheric pollutants: mass spectrometry studies, Sci. Total Environ. 1994, 152, 125-34.

124. Cooksey, C.J. The Synthesis of minor Components of Shellfish Purple: Bromoisatin, Bromoindigotin and Bromoindirubins, from Dibromoindigotin, Beitr. Waidtag. 1998, 7, 71-74.

125. Voss, G.; Schramm, W. Selectively C-deuterated indigotins, Helv. Chim. Acta, 2000, 83, 28842892.

126. Schweppe, H. Handbuch der Naturfarbstoffe. Vorkommen, Verwendung, Nachweis, Ecomed: Landsberg/Lech 1993, 304-314.

127. Spanier, E.; Karmon, N.; Linder, E. Bibliography concerning various aspects of the purple dye, Levantina, 1982, 437-447; updated at http://www.tekhelet.com/pdf/ta02.pdf.

128. Cooksey, C.J. Bibliography: Tyrian (Shellfish) Purple, Dyes Hist. Archaeol. 1994, 12, 57-66; updated at http://www.chriscooksey.demon.co.uk/tyrian/cjcbiblio.html.

129. Cardon, D.; du Chatenet, G. Guide des Teintures Naturelles, Delachaux et Niestlé: Lausanne, 1990, pp. 338-354.

130. Clark, R.J.H.; Cooksey, C.J.; Daniels, M.A.M.; Withnall, R. Indigo, woad, and Tyrian Purple: important vat dyes from antiquity to the present, Endeavour, 1993, 17, 191-199.

131. Spanier, E (Ed), The Royal Blue and The Biblical Purple; Argaman and Tekhelet, Keter Publishing House Jerusalem Ltd.: Jerusalem, 1987.

132. 'How could the purple be used? Today when chemical manufacturers produce a torrent of materials for industry, which, with great ease and perfection, provide fine and strong colours, how can we expect to see this small animal which provides the purple, though beautiful and long-lasting, being used by industry? It is hardly likely that the purple will return to favour.'

133. http://www.kremer-pigmente.de/intl.catalog/epigmen08.htm.

Sample Availability: Samples of 6,6'-dibromoindigo, 6-bromoindigo and indirubin are available from MDPI.

(C) 2001 by MDPI (http://www.mdpi.org). Reproduction is permitted for noncommercial purposes. 